\title{
After the Sanctions: Policy Challenges in Transition to a New Political Economy of the Iranian Oil and Gas Sectors
}

Tamás Dudlák

Doctoral student, International Relations Multidisciplinary Doctoral School, Faculty of Social Sciences, Corvinus University of Budapest, Hungary

1093 Budapest, Fővám tér 8. (Hungary)

tamas.dudlak@stud.uni-corvinus.hu

\begin{abstract}
This article discusses the prospects of Iranian domestic energy sector by focusing on the latest political and economic developments taking place in connection with the hydrocarbon industry. Although after partial lifting of the sanctions, substantial changes in the Iranian energy sector may present a new, favorable environment for international investments, the political economy of hydrocarbon management in Iran plays a significant role in the definition of current and prospective stakeholders, their aims and interests. This paper analyses existing policies and policy challenges of hydrocarbon management by contextualizing them with historical and political factors.
\end{abstract}

Considering the recent prospects in the Iranian hydrocarbon sector, it is worth keeping only the lower expectations concerning the production boom of the Iranian hydrocarbon industry: due to external market trends (low oil price, oversupply in the market) and a long redistribution process, the most probable scenario proposes a slow and continuous transformation in the oil and gas sectors of the Islamic Republic. In practice, it means that both the extension of export capacity and the involvement of international companies will take place in a gradual, regulated way, in which all the interests of major Iranian political and economic stakeholders have to be considered. 


\section{Keywords}

sanctions, oil, natural gas, Iran, subsidy, investment

\section{Introduction}

This article discusses the prospects of Iranian domestic energy sector by focusing on the latest political and economic developments taking place in connection with the hydrocarbon industry. Although after partial lifting of the sanctions, substantial changes in the Iranian energy sector may present a new, favorable environment for international investments, the political economy of hydrocarbon management in Iran plays a significant role in the definition of current and prospective stakeholders, their aims and interests. This study only deals with oil and natural gas issues within the energy sector. In this respect, my aim is to analyze the economic and political opportunities offered by the partial elimination of the sanctions against Iran at the beginning of 2016 together with the expansion of Iranian oil and natural gas industries. In this article, there is no coverage on the technical details of these topics unless they are indispensable for understanding the political economy of oil and gas issues in Iran. Renewable energy sources do not have this political and geopolitical impact, therefore they are not addressed in the text ${ }^{1}$ and the environmental issues are for now out of scope as well. ${ }^{2}$ Similarly, any prospects concerning coal and nuclear energy and all their political implications will not be discussed in this article.

The importance of oil and gas resources in the Iranian energy policy is based on two factors. On the one hand, Iran gains almost all its energy from hydrocarbons, ${ }^{3}$ on the other hand, oil and

\footnotetext{
${ }^{1}$ For further details: al-Monitor (2016a) and Tabatabaei et al. (2017).

${ }^{2}$ For further discussion, see Talaei et al. (2014), Eshraghi-Ahadi (2016) and Tabatabaei et al. (2017).

${ }^{3}$ Out of the total energy mix of Iran oil has $37 \%$, natural gas has $61 \%$ share, while nuclear and water power constitute only 1-1\% (Rzayeva, 2016).
} 
gas by their nature connect Iran to the international community, to the regional and the global market. This interconnection has become particularly significant during the sanctions regime showing that changes in these sectors were not only had an influence on the domestic affairs, but it determined the international status of the country as well. Oil and gas as significant profitable raw materials are not only the basis of the economy in Iran, but they constitute strategic and political instruments that interact with the Iranian domestic and foreign policy and are often utilized in diplomacy by the policy makers. Since the strategic sectors (military, energy) and their development are concentrated in the hand of the political leadership of Iran, the interrelations between politics and hydrocarbon management cannot be exaggerated. Hydrocarbon revenues are often used for a dual, contradictory, target by the governments: first, to accomplish economic and social transformation (industrialization, modernization), second, to maintain the status quo in the domestic power relations (Smith, 2007). The strong ideological commitment of the leadership, the politically influenced economy and the fact that the overall economic performance depends on the effectiveness of the hydrocarbon sectors make the analysis of the political sphere even more relevant in the case of Iran.

This paper is organized as follows: after the section on literature review and methodology, the basic data on the existing resources of oil and natural gas are provided (economic aspect). Then, the historical developments of the hydrocarbon sector are summarized in order to understand the "package" of traditions influencing current policy-making and the Iranian political and economic elite (historical aspect). The economic sanctions imposed by the international community make the case of Iran unique: their effects are addressed before the discussion of the current governmental perspective on the domestic hydrocarbon industry (subsidies, monopolies) (political and legal aspect). The relevant events and data of the postsanctions period lead the discussion to the political, economic, financial and legal background of investment opportunities in Iran. The penultimate section of this paper evaluates the latest 
trends of the oil, gas and petrochemical industries offering opportunities for further development. The article closes with conclusions and policy recommendations concentrating on the political and economic policy factors that would enhance the implementation of a more effective system.

\section{Literature review and aim of this research}

Recently, there have been a number of studies that have investigated several specific energy policy areas and technical issues of energy in Iran such as the gasoline consumption in the transportation sector (Jafari and Baratimalayeri, 2008), the impact of feed-in tariff policy (Tabatabaei, 2017), the practical application of the buy-back service contracts (Ghandi and Lawell, 2017), or the latest reform attempts in the electricity industry (Yousefi et al., 2017). Beyond these particular studies, the seminal work of Elham Hassanzadeh (2014) provides a comprehensive picture of the domestic and international challenges of the natural gas sector in Iran in the period of sanctions.

Another part of the literature provides different scenarios for the future production of oil and gas in Iran by the intensive use of production and consumption data, therefore putting rather less emphasis on the political aspects of supply and demand management (Abbaszadeh, et al., 2013; Azadi and Yarmohammad, 2011; Kiani and Pourfakhraei, 2010). Some of the recent literature (Jalilvand, 2013; Vakshouri, 2017) deals with the international prospects of the oil and gas policies of Iran, but they also contain relevant data on the development of the domestic energy policy. For example, Esen and Oral (2016) analyzed four countries having the largest natural gas reserves in the world (Russia, Iran, Qatar, Turkmenistan) from political and economic perspective putting emphasis on the international context, its differences and similarities. The approach used here is different in a sense that the focus is only on Iran and the interconnection of political and economic issues in the domestic arena. My main contribution is to reemphasize the importance of the political and economic "embeddedness" of Iran 
concerning its hydrocarbon management policies. Compared to these studies, this article extends the research to the post-sanctions era as well and provides the latest data on the issues discussed here. Moreover, this paper analyses existing policies and policy challenges of hydrocarbon management by contextualizing them with historical and political factors. Beyond the "traditions" of oil and gas sectors influencing energy choices, understanding organizational dynamics and the role of domestic political "powerhouses" in economic decision-making strengthens the "human elements" of energy policy analysis (Sovacool, 2014). These "human elements" consist of legal, political, economic, and historical variables.

In the following sections, my aim is to provide a reliable assessment for policy makers and all interested parties on the domestic prospects and challenges of the post-sanction Iranian hydrocarbon sector. With this overview, it will be possible to identify the present state and the future needs of the Iranian hydrocarbon industry as well as its energy consuming sectors. The significant social and economic changes such as industrialization, modernity, population growth and the widespread use of information and communication technologies offer a new picture on the internal dynamics of the Islamic Republic (Social Change, 2013). Given the current circumstances provided by the partial elimination of the sanctions, the necessity of a comprehensive assessment on the performance of the Iranian hydrocarbon sector appears relevant.

\section{Natural gas and crude oil resources in Iran - data}

From an international perspective, Iran is a significant player due to its notable oil and natural gas resources. According to BP plc (former British Petroleum), Iran disposes of 158 billion barrels proven oil reserves and 33.5 trillion cubic meter natural gas reserves (BP, 2017). Now, Iran ranks in the $4^{\text {th }}$ place with regard to the size of oil its reserves, while standing on the first position in terms of its gas reserves (closely followed by Russia). Iranian crude oil constitutes $10 \%$, natural gas $17-18 \%$ of total reserves of the world. This huge amount of hydrocarbon 
wealth means that potentially there is no chance for these resources to be exhausted in the medium term. (Figures 1a, 1b, 1c and 1d)

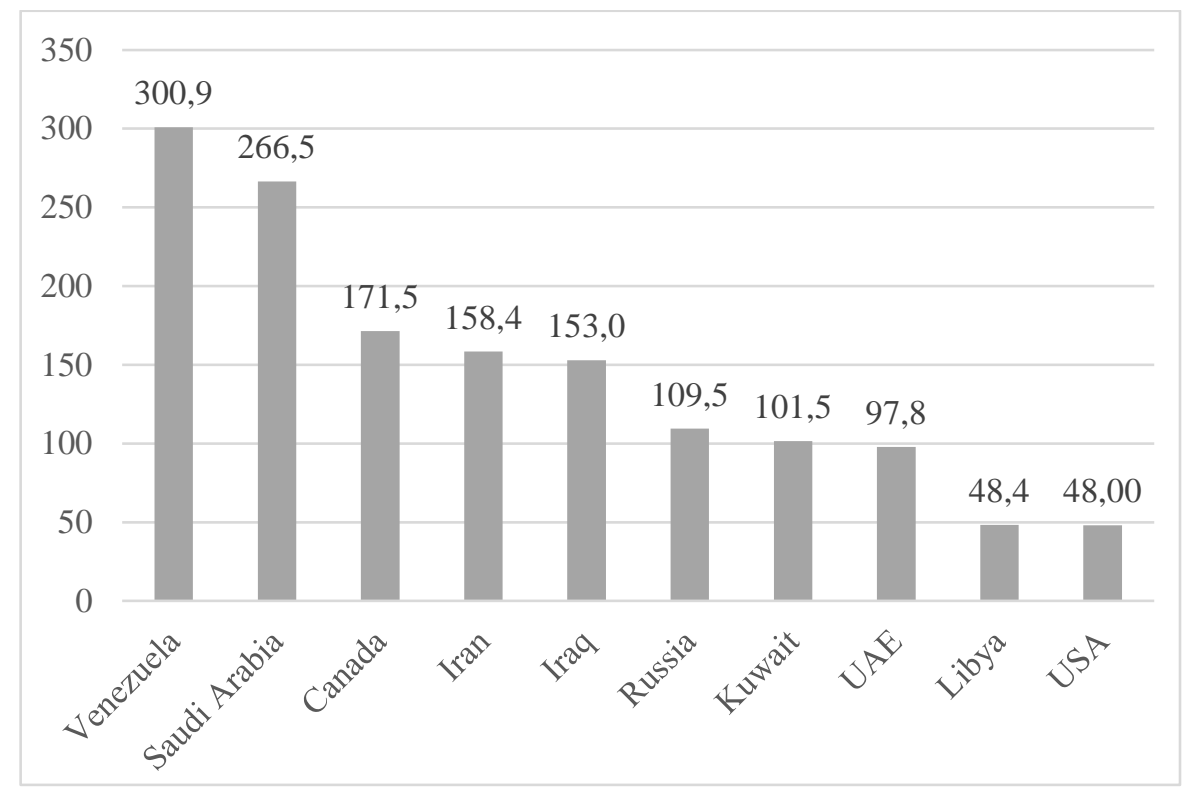

Figure 1a. Countries of the largest oil reserves (end of 2016) in thousand million barrels (BP 2017)

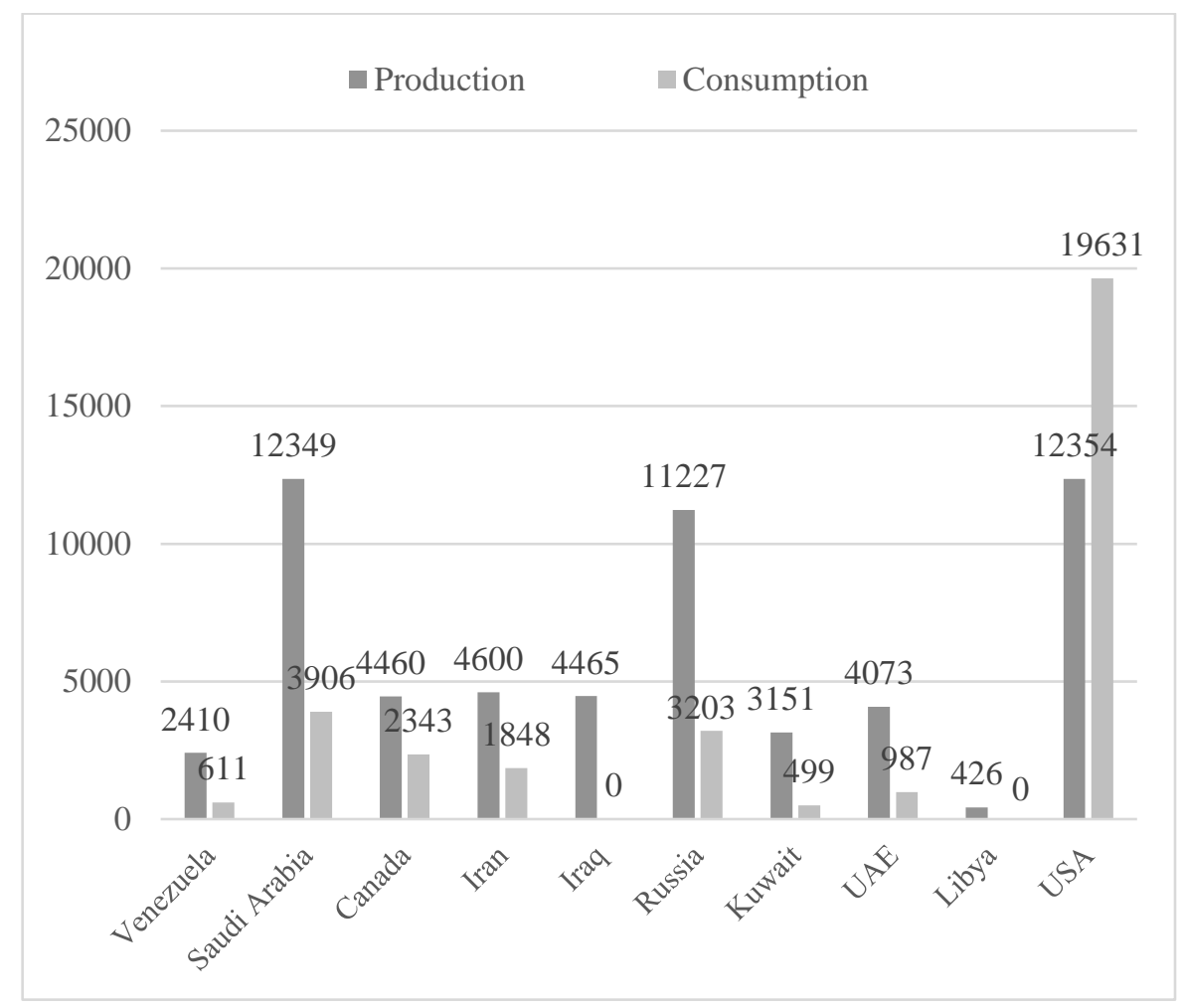

Figure 1b. Countries of the largest production and consumption (end of 2016) in thousand barrels per day (BP 2017) 


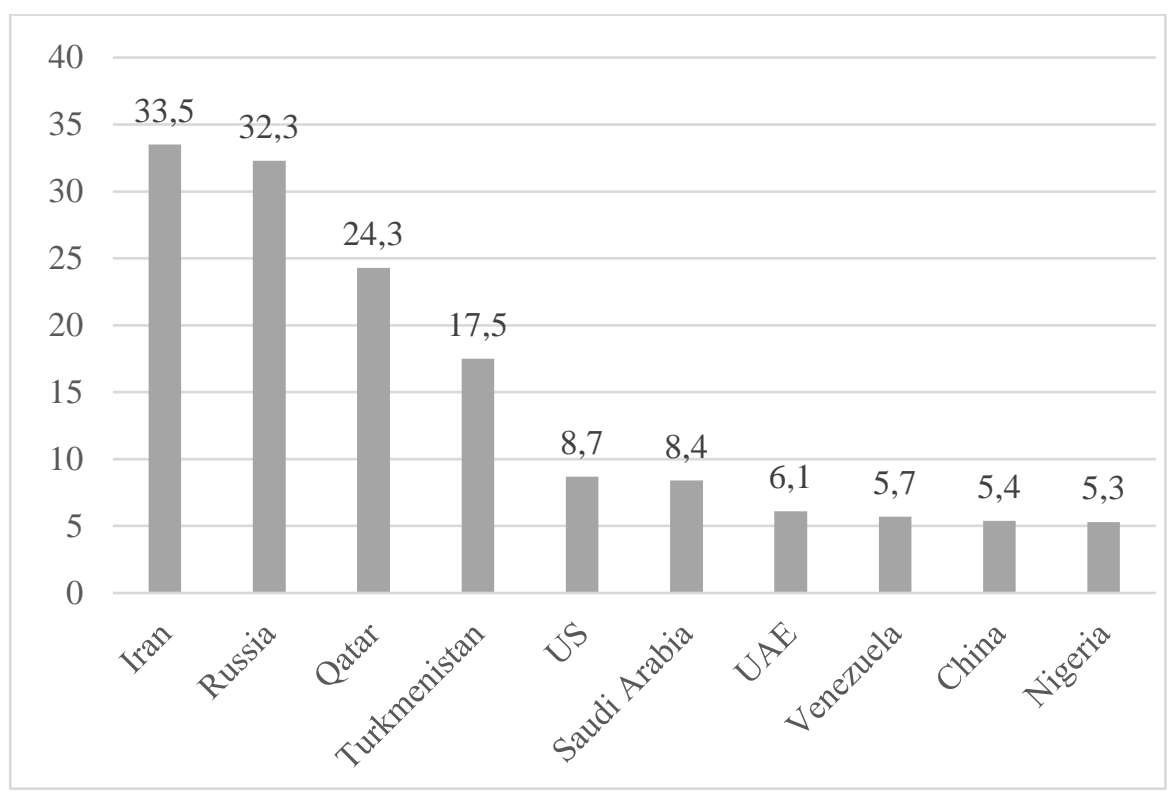

Figure 1c. Countries of the largest gas reserves (end of 2016) in trillion cubic meters (BP 2017)

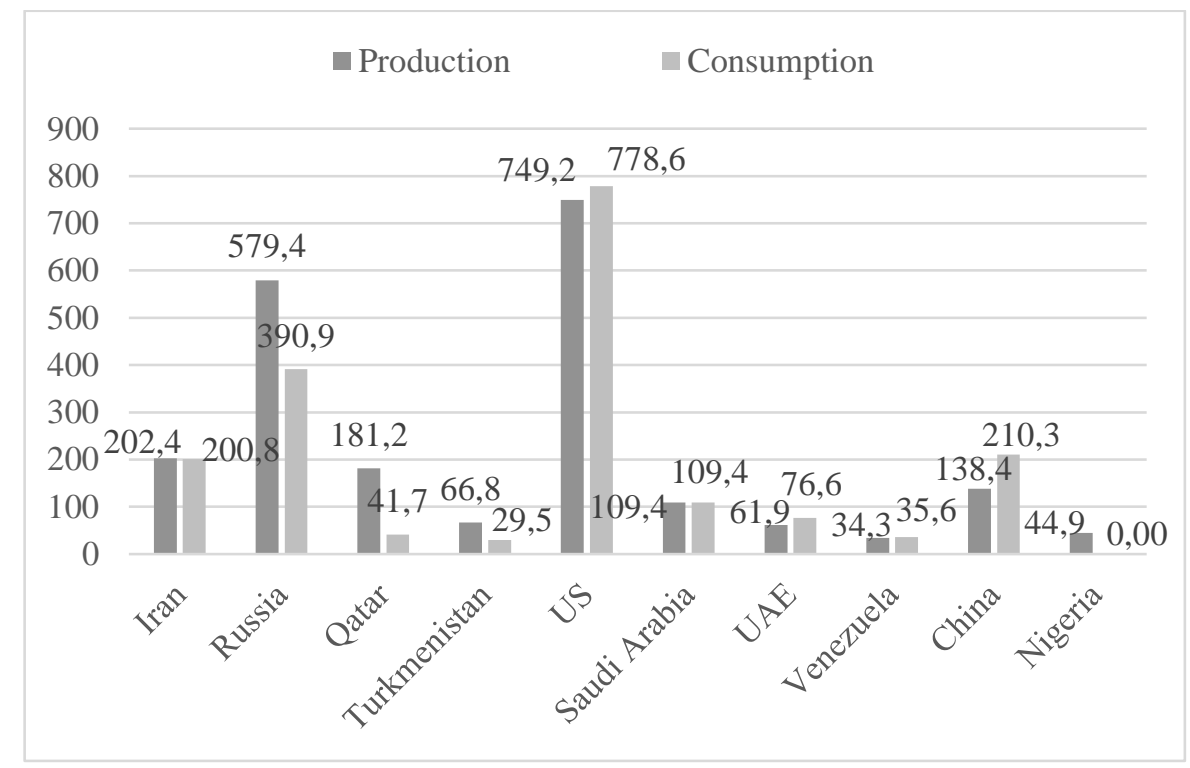

Figure 1d. Countries of the largest gas production and consumption (end of 2016) in bcm (billion cubic meters) (BP 2017)

62 onshore oil fields, 16 offshore oil fields, 20 onshore gas fields, and 2 offshore gas fields are in operation in Iran

The largest part of the Iranian hydrocarbon resources can be found around the Gulf area Khuzestan holds $80 \%$ of oil reserves of the country 
Imbalance in the geographical distributions-being far from the large population centers of the north — creates challenges for infrastructural development

Since 1999 there have been no significant recent discoveries of giant oil fields

The largest onshore oil fields are Ahwaz, Marun, Gachsaran and Agha Jari, as well as Farzad and Foruzan offshore fields shared with Saudi Arabia.

South Pars gas field shared with Qatar plays the most important role by providing $54 \%$ of the current natural gas production of Iran (47\% of the total reserves)

Significant natural gas production comes from other gas fields: Kish, Golshan, Ferdowsi and North Pars

Compared to the average world success ratio of $30-35 \%, 79 \%$ of natural gas explorations in Iran are successful

Table 1. Iranian oil and gas fields. Data compiled by using (Investiran, 2017;

Vakshouri, 2015; Bárdossy, 2007; Kalehsar, 2015; Rzayeva, 2016).

Compared to its excellent physical attributes as Table 2. shows, the Iranian oil exports rank only third place internationally, considerably lagging behind Saudi Arabia in first position. In this sense, the natural gas potential is also underutilized, partly because internal consumption uses up the whole production capacity making the exports of natural gas to regional and world markets difficult. However, Iran ranks third in natural gas production (behind Russia and the USA). To discuss the issue of this discrepancy between potential and reality, this article relies on historical data and analysis of economic policies beyond sheer economic reasoning in order to comprehend the internal and external factors that play roles in the relative under-performance of the Iranian hydrocarbon sector.

\title{
Past tendencies in the management of oil and gas sectors
}

\author{
1901 First concession of oil in Iran (Persia) \\ 1908 First successful oil exploration \\ 1951 Establishment of NIOC \\ 1953 Fall of Mosaddegh \\ 1955 Establishment of NITC \\ 1973 First oil crisis \\ 1979 Second oil crisis \\ 1979 Islamic Revolution \\ 1980-1988 Iraq-Iran war
}




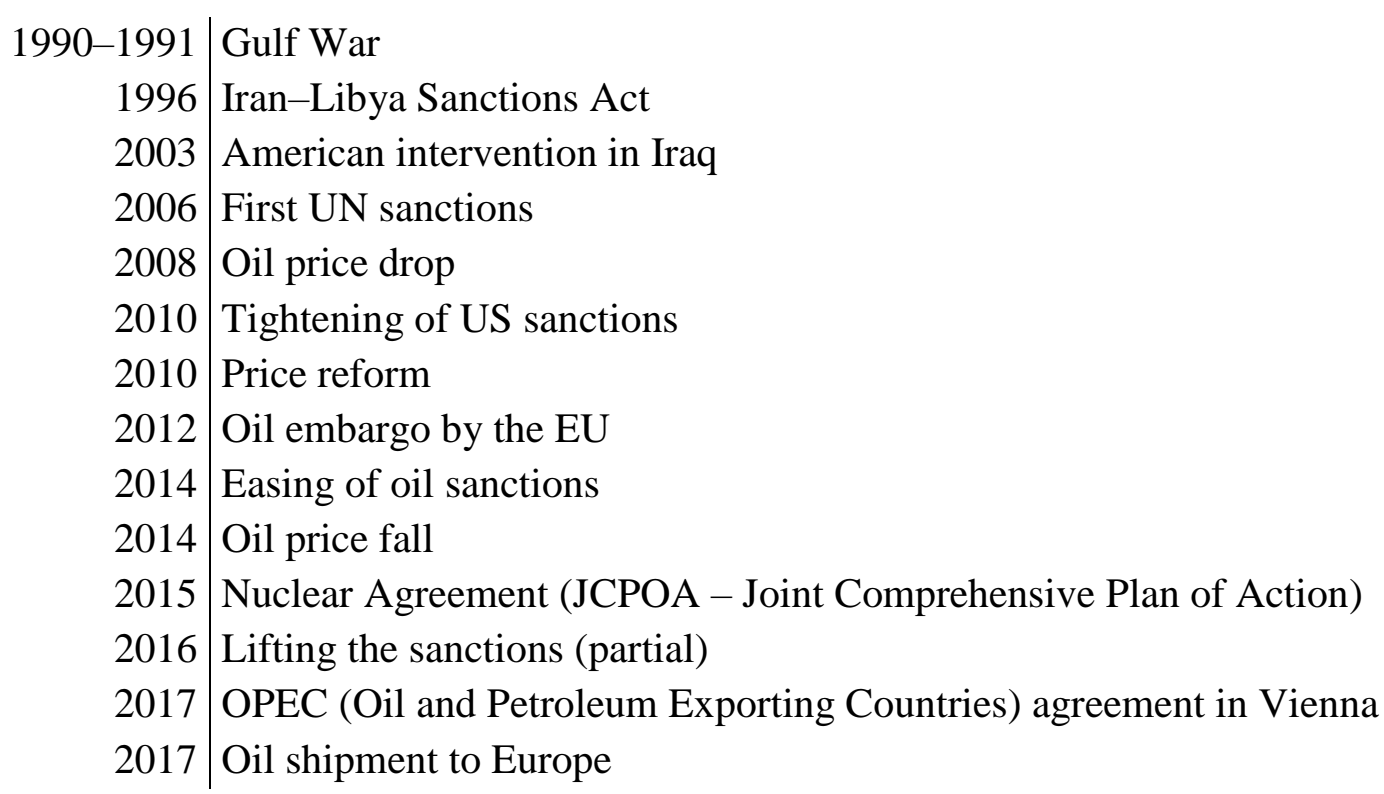

Table 2. Macro events in the Iranian energy industry

In Iran, the first oil exploration started in 1901 (at that time, it was known as Persia) followed by the decision of the shah of the Qajar dynasty, Mozaffar al-din (1896-1907) who- unaware of the strategic importance of oil— provided the British investor William Knox D'Archy (18491917) the right to exploration, production, processing and export of Iranian crude oil for 60 years. In 1908, for the first time in the Middle East, oil was discovered in the Masjed-e Soleyman (Khuzestan) area (OurWorld, 2014). The Anglo-Persian Oil Company (APOC, the predecessor of the present day British Petrol) founded in 1909, controlled this concession on condition that only $16 \%$ of the profit was left to Iran. This extremely disadvantageous condition for the locals contributed to the struggle against foreign dominance and attempts of colonization through foreign oil companies in Iran during the $20^{\text {th }}$ century. One of the most significant events in this time period was the nationalization of oil production, ordered by Prime Minister Mohammad Mosaddegh (1951-1953) in 1951, and the establishment of the National Iranian Oil Company (NIOC). Despite the sanctions imposed by the Western powers against the nationalist government, oil production continued but exports faced many difficulties. An international ban on buying Iranian oil products broke in 1953 when Iran managed to sell oil to Italy and Japan (Vakshouri, 2015). To hinder the recovery of the Iranian economy and their 
increasing shares in the oil industry, British and American secret services intervened and managed to topple the Mosaddegh government in the same year (Zerohedge, 2017a). (Table 3.)

During this short intermezzo of Mosaddegh, the Iranian leadership recognized the importance of direct connections with the world market, consequently, the government established the National Iranian Tanker Company (NITC) in 1955, which has now become the second largest oil shipping company (presently, it has 67 oil tankers) (Shana, 2014). After 1953, the NIOC itself had only limited influence on the oil industry, because until 1979 it was under the management of a consortium, in which British Petrol possessed the largest share $(40 \%)$ (Vakshouri, 2015). The restoration of Mohammad Reza Pahlavi’s power (1941-1979) meant strong British and American influence over the Iranian economy. However, Western technological expertise and financial investments led to a greater efficiency in the hydrocarbon sector. As a result, Iran reached its all-time high oil production in 1976 (6.7 million bpd [barrel per day]) (Oilpro, 2017).

The Islamic Revolution in 1979 led to the fall of the Shah and to the deterioration and cessation of relations with the Western world. By losing the United States as a key trade partner, Iranian oil exports shifted towards Asian markets. ${ }^{4}$ Due to international isolation, the long war with Iraq (1980-1988), and the change in the domestic management of the industry, ${ }^{5}$ the oil production of Iran fell from an average 4 million bpd to less than 1.5 million by 1982 (Hassanzadeh, 2014).

Natural gas production in Iran had started before the revolution and expanded gradually. The amount of gas output reached $20.3 \mathrm{bcm}$ in 1975, and increased to $87 \mathrm{bcm}$ by 2005 (Bárdossy, 2007.). (Figures $2 \mathrm{a}$ and $2 \mathrm{~b}$ ) Natural gas boom was induced by its growing role in the residential

\footnotetext{
${ }^{4}$ This shift included Israel as well: the formerly flourishing relations (during the oil embargo of 1973, Iran provided most of Israel's oil) turned into enmity; the new government's policy preferred the oil to be shipped to Muslim countries instead.

${ }^{5}$ The overgrown state sector is also the legacy of a government-run closed war economy of the 1980s.
} 
and industrial consumption thus the rising demand in these sectors meant further increase in the share of natural gas in the Iranian energy mix: in 1990, natural gas provided only $15 \%$ of the full energy consumption; in 2011 this number had reached 54.67\%. The Islamic Republic prioritized supplying and providing access to domestic consumers with the necessary amount of natural gas by developing the gas network in residential areas (Hassanzadeh, 2014).

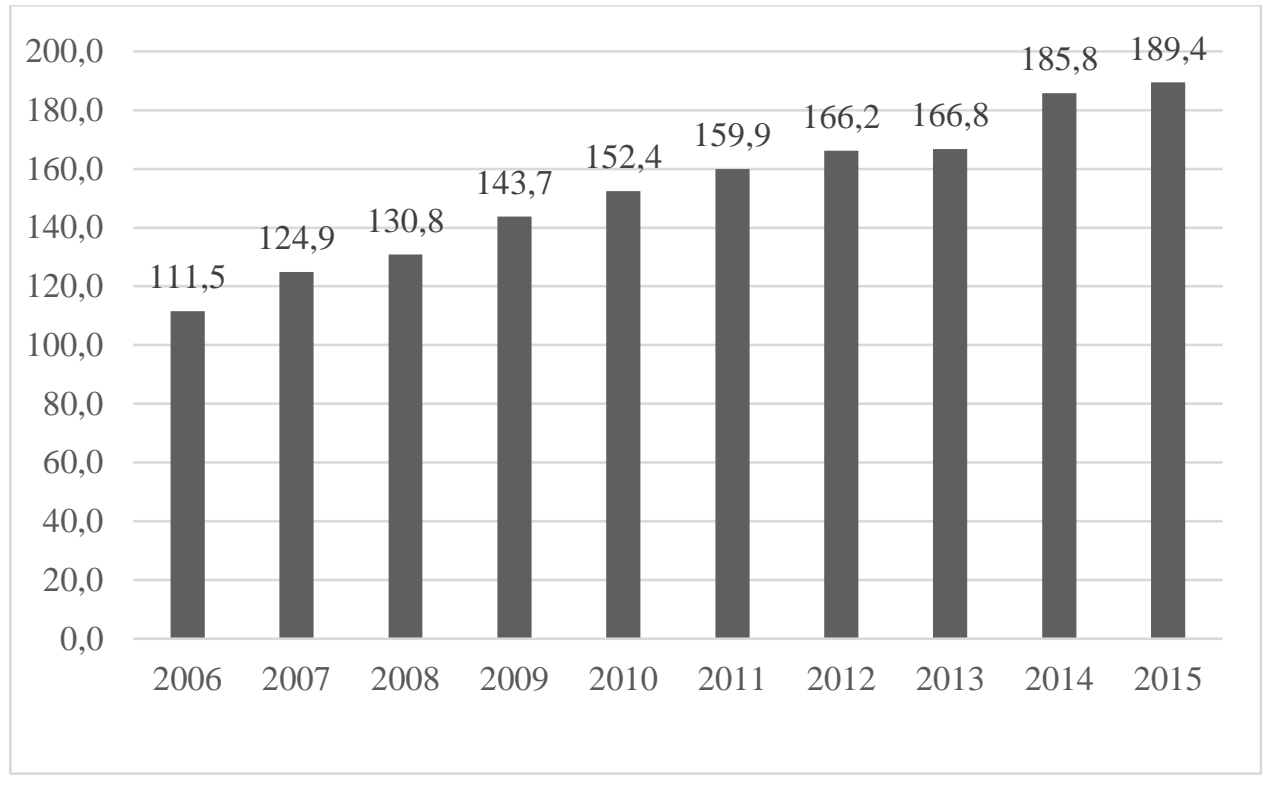

Figure 2a. Natural gas production of Iran in bcm (BP 2017)

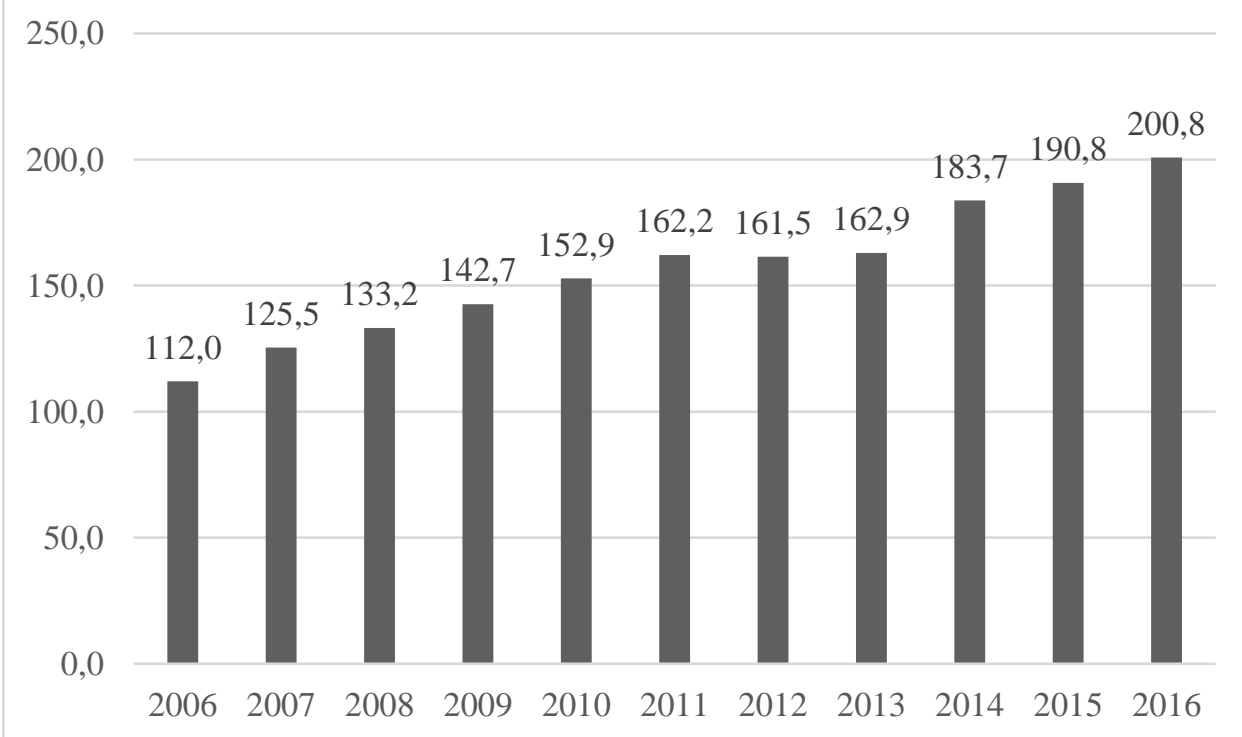

Figure 2b. Natural gas consumption of Iran in bcm (BP 2017) 
Concerning natural gas exports within the last two decades, Iran swings between the statuses of net importer and net exporter. From 1997 onwards, imports of natural gas exceeded exports and the balance became negative several times. Data from (Figure 3) does not contain the amount lost due to gas injection, flaring and intentional or unintentional leakage. ${ }^{6}$ Added to the technical difficulties, consumption shows seasonal fluctuations as well: during winter months gas consumption can be three times higher than in the summer because of the extensive use of heating, but in the summer demand for electricity increases due to high usage of air conditioners (Rzayeva, 2016 and Yousefi et al., 2017).

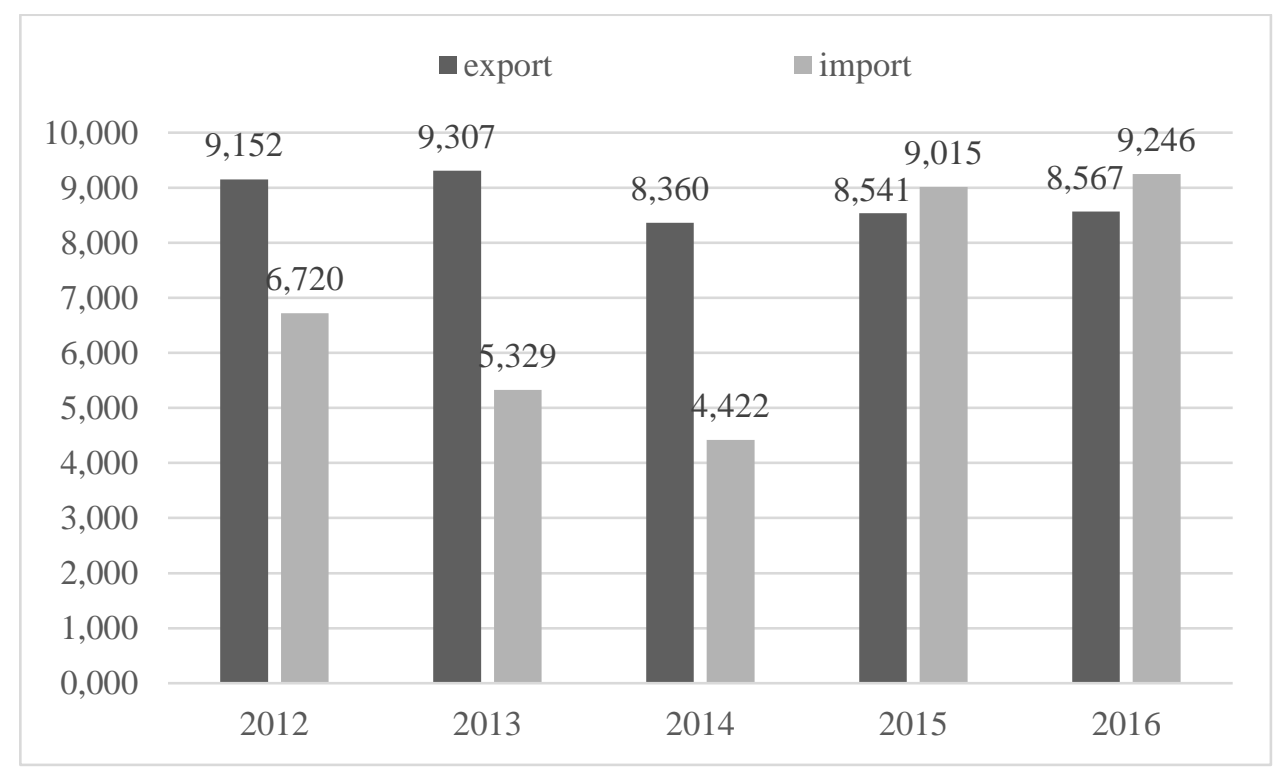

Figure 3. Natural gas export and import of Iran in bcm (OPEC 2017)

\section{Sanctions and reactions}

As a consequence of regime change in 1979, corporations of Western origin rarely risked cooperation with the new Iranian leadership that defined itself against the Western powers was waging a devastating war on the neighboring Iraq (1980-1988) creating an unfriendly

${ }^{6}$ The gross natural gas production was $244.5 \mathrm{bcm}$ in 2014 . From this, $32 \mathrm{bcm}$ was injected, $15.5 \mathrm{bcm}$ was flared and $23 \mathrm{bcm}$ had been lost. The last two numbers are high owing to the lack of technical conditions and proper infrastructure. Sometimes during oil production, it is worth flaring the gas more than extracting, storing and transporting it (Rzayeva, 2016). 
environment for investors. Under these circumstances, Western powers tried to isolate the Islamic Republic of Iran by indirect political and economic measures. Sanctions imposed by them have expanded during the course of the years; the most important of them being the American in 1996 (Iran-Libya Sanctions Act) that made the American investments in technology and finance legally impossible. The USA initiated the ban on the Iranian energy industry in 2010. Apart from these Western restrictions, in 2006, 2007, 2008 and 2010 the United Nations Security Council implemented several economic sanctions against Iran (Bahgat, 2015). Sanctions of 2012 imposed by the European Union on the Iranian energy sector have had serious consequences for the industry. It not only prohibited the energy investments in Iran, but embargoed the import, purchase and transport of Iranian oil to the EU (European Union) (Kalehsar, 2015). These measures were deliberately aimed at one of the most sensitive sectors of the Iranian economy (besides the banking sector) since oil and gas industries are the most susceptible to external changes: Iran maintains its economic connections with the world market mainly through oil exports, which makes up a significant portion of the state budget $(7 \%$ in 2017) (Iran 2017 Budget, 2017). Since oil export is essential to the supply of foreign currencies, it plays a role in the balance of export and import. It was obvious that artificially low oil and gas prices in Iran will have a negative effect on public spending thus leading to public discontent. (Figure 4) The underlying idea was that although the system cannot be overthrown by these means, reaching the system's "threshold of pain" can put pressure on the Iranian leadership to drive the Iranian politics and economy back to the "rules" of the international community (Yong-Hajihosseini, 2013). 


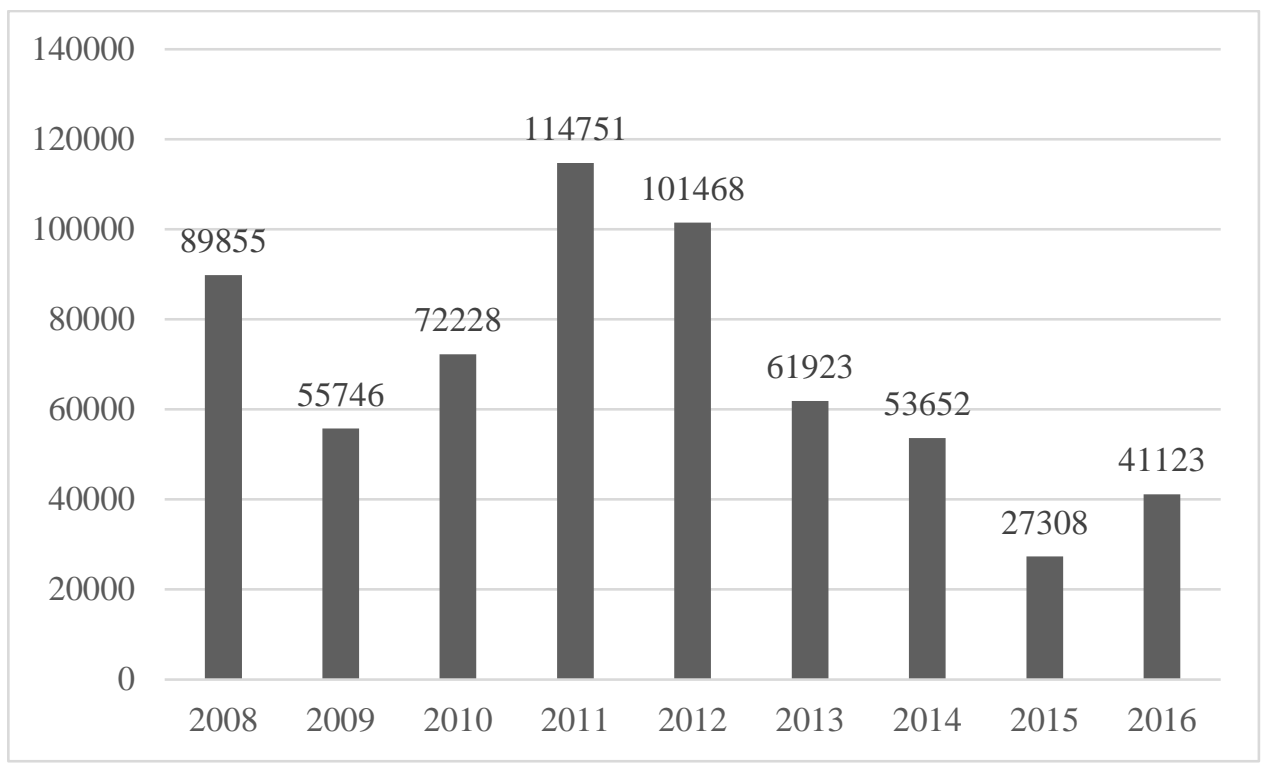

Figure 4. Values of petroleum exports of Iran in million USD (United States dollar) (OPEC 2017)

Data as shown in (Figures 5a and 5b) clearly proves the setback in the output of oil industry: before 2012 Iran exported 2.2 million barrels (600,000 to Europe and the rest to Asia) from the total production of 3.75 million bpd. In June 2012 oil exports went down to 1.74 million bpd and 1 million bpd in July. Shipping to Western Europe totally stopped, while in case of the largest Asian partners (China, India, Japan, South Korea, Turkey) Iran faced 50\% drop compared to the beginning of the year. According to estimations, Iran lost 3.8 billion USD incomes every month (based on the 2012 average price of oil, 110.6 USD per barrel) (Abbaszadeh, 2013) not to mention the $40 \%$ depreciation of the rial and the high inflation rate (Yong-Hajihosseini, 2013). Taking approximately 1.5 million bpd oil off the market has caused a 125 billion USD revenue loss for Iran since 2012 (Wang 2017, 273.). 


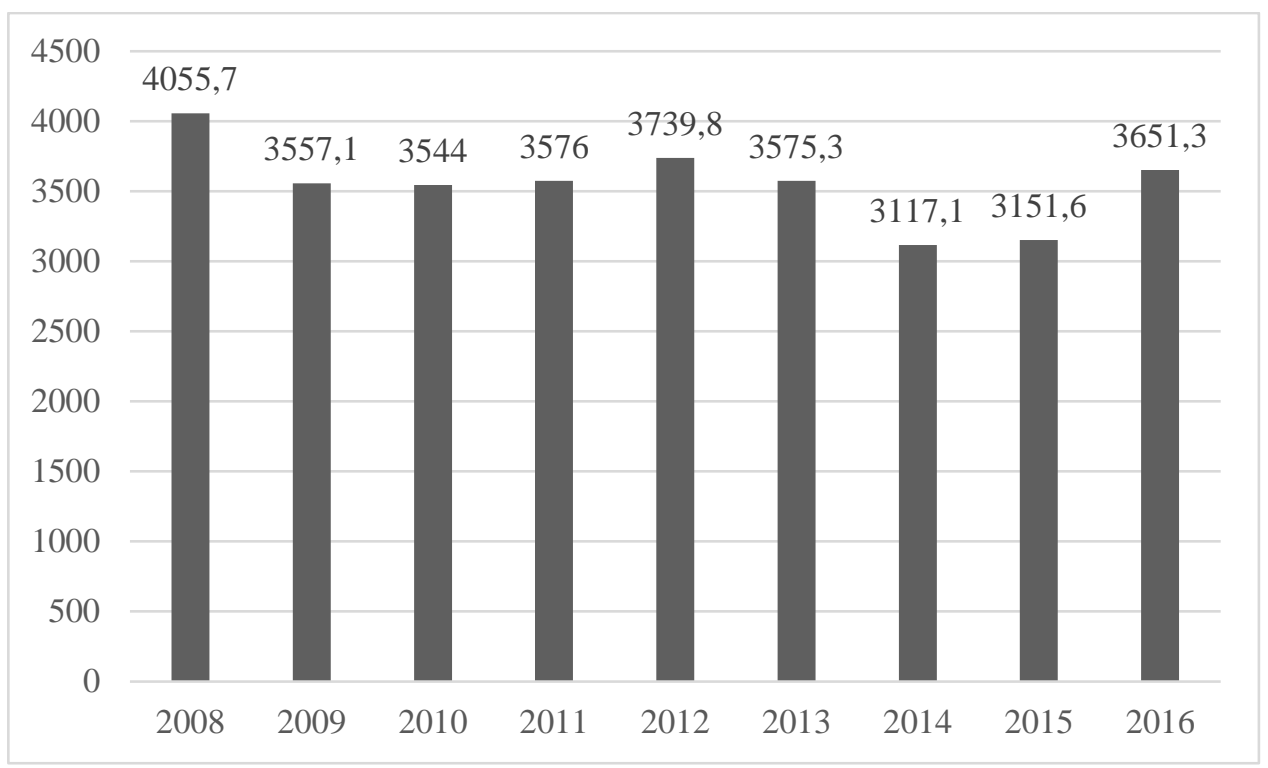

Figure 5a. Oil production of Iran in 1000 bpd (OPEC 2017 and BP 2017)

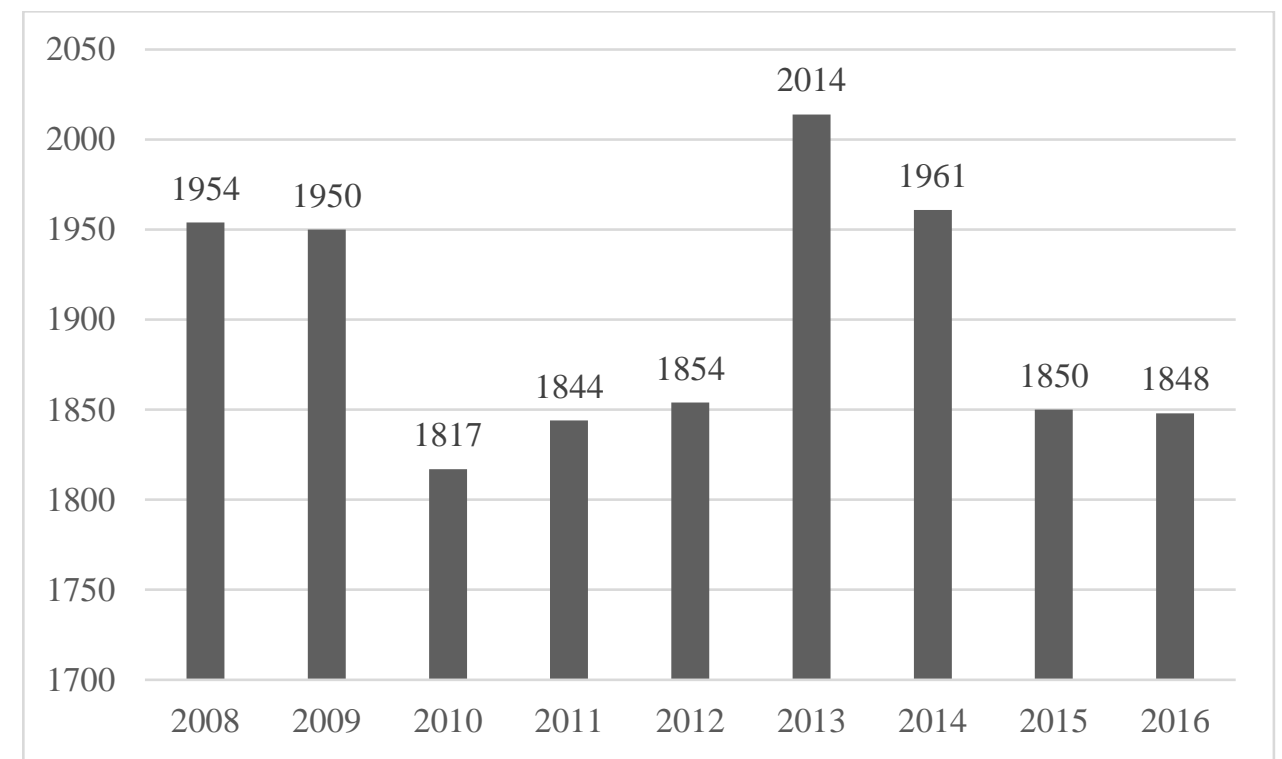

Figure 5b. Oil consumption of Iran in 1000 bpd (OPEC 2017 and BP 2017)

Change in export structure (Figure 6) indicated transformations in the world oil market. The biggest winners of the Iranian setback were Saudi Arabia, Iraq and Russia, together they increased their production by 2.5 million bpd counterbalancing the Iranian share missing from the market (Munro, 2016). Since there is a similarity in quality and characteristics of Iranian crude oil grades to those exported by Gulf countries and as they reacted immediately, there was no deficit in the international oil supply after 2012 (Oil sanctions, 2012). 


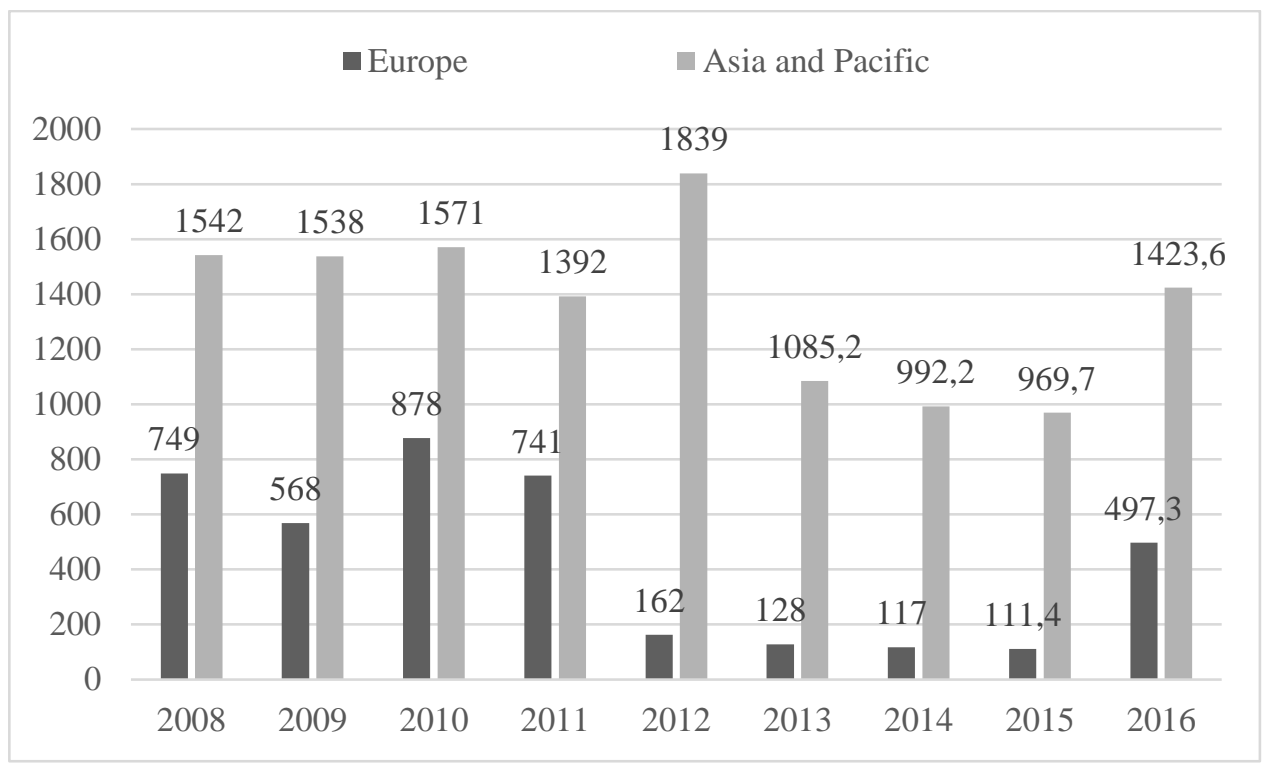

Figure 6. Oil export of Iran by destination in 1000 bpd (OPEC 2017, OPEC 2012, OPEC 2010-2011, OPEC 2009)

Sanctions of 2012 had their negative impacts on the growing natural gas market as well. Lacking the necessary capital and technology, investments almost stopped in the industry, thus the fields with obsolete production management quickly began to deplete. ${ }^{7}$ Sanctions have put obstacles in the development of different phases of the aforementioned South Pars field and other oil and gas fields as well. ${ }^{8}$ For example, CNPC (China National Petroleum Company) started its activity in early 2010 on the development phase 11 of South Pars, but in 2012 the company realized the risk and the lack of technological expertise following the expansion of economic sanctions that resulted in leaving the project (Wang, 2017).

Due to the inaccessible Western technology, Iran has no LNG (liquified natural gas) terminal yet. In 2005, in cooperation with the French Total, the Spanish Repsol, the Anglo-Dutch Shell and the Malaysian Petronas a large LNG development project was initiated, but it turned out to be a failure by 2008 (Tanchum, 2015). After 2010, an Iranian attempt to attract Chinese and

\footnotetext{
${ }^{7}$ Due to the high depletion rate of oil fields, the annual amount of loss is estimated to be 400,000 barrels. (Reuters 2016b) The global depletion rate is 5-6\%, in Iran it is 8\% (Azadi-Yarmohammad, 2011).

${ }^{8}$ Owing to the more developed status of the Qatari side, Iran is losing natural gas from the South Pars field, since gas is flowing to the Qatari side to fill the vacancy arising after the intensive production of that part of the field (Stevens 2015 5.).
} 
South Korean companies to invest in the LNG sector was not successful (Jalilvand, 2013). These setbacks contributed to the emergence of Qatar as the largest LNG supplier of the world. Now, the East-Asian markets' demand is secured by long-term contracts, thus there is only a few opportunities to receive Iranian LNG in the near future. In the global LNG market, beyond Qatar, Iran has to cope with the competition of several newly emerged LNG suppliers such as Canada, the United States or Australia (GSN, 2016).

Unfortunately, up till the present there has been a lack of verifiable data ${ }^{9}$ on the economic stability and capacity of Iran, therefore it is difficult to estimate the exact economic robustness of the system facing economic sanctions. Except for oil exports, Iran has been independent from the world economic trends owing to the fact that the country is constantly "out of the system" following the Islamic Revolution. ${ }^{10}$ Constant international challenges (almost forty years of trade restrictions) forced Iranians to adopt a certain survival strategy, resulted in the emergence of the so-called "economy of resistance" as the people and the leadership managed to find possible ways to bypass the sanctions regime and developed a kind of subsistence economy.

Nevertheless, external factors listed above contributed to the weak performance of the Iranian oil and gas sectors, since they hindered the inflow of necessary technology and isolated Iran from the world market demand. Moreover, the regime change in 1979 caused internal transformations in the management of oil and gas industries that also played a significant role in the weak production performance of the last decades.

\footnotetext{
${ }^{9}$ Data on the energy sector is often not accurate, but even so, main trends can be deduced from them. OPEC countries often exaggerate their reserves statistically in order to receive larger production quota from the organization (Azadi-Yarmohammad, 2011 and Esen-Oral, 2016).

${ }^{10}$ This defended Iran during 2008; without significant economic ties with the West, the country was not affected by the economic crisis originating from the United States.
} 


\section{The dynamics of domestic actors and the price control regime}

The economic sanctions showed Iran's dependency on oil revenue. ${ }^{11}$ The overall efficiency of economic sanctions in the literature is a highly debated topic (Lektzian et al., 2007 and Hajihosseini, 2013). By definition, every economic sanction (partly) aims at the production system of the target country thus causing the termination of cooperation in certain economic sectors of the respective parties. The rationale behind the use of sanctions is that economic deprivation of the population can be translated into political or policy change of the existing regime (Lektzian et al., 2007). In the case of Iran, this idea has been proven wrong as the people reacted on the external threat differently and finally, they remained loyal to the system or in other words, they pulled together and stood aloof from the pressure coming from outside. In case of a sanction, the general conviction is that utilizing the idea of nationalism strengthens the endurance of societies against any types of external pressure (David, 1991), if the government manages to merge the idea of its own stability into the economic stability of the country. In Iran, although the leadership remained intact, the hydrocarbon sector suffered from the direct and indirect consequences of the sanctions.

There is a consensus in the literature that the main objective of the Islamist leadership is to remain in power by maintaining the status quo even if the cost is too high for the country itself (Posch, 2006; Ansari, 2010; Parsi, 2013). Although the Iranian political system is far from the Western liberal democracies based on transparency and accountability, the leadership has certain connections to popular legitimacy through some limited democratic means in the system (elections, parliament). Thus, Iranian institutions have to take both the domestic audience and the opposition into account to successfully maintain their grasp on the Iranian society. The long period of economic and political isolation gave the government the pretext to build up a more

\footnotetext{
${ }^{11}$ According to the IMF, in the Iranian year of 2015 and 2016 (until 19 March 2016) the oil incomes coming from exports constituted $29 \%$ of the central budget (IMF, 2015).
} 
centralized state in defense of the population. This is an example of how the sanctions sometimes yield counterproductive results (Heuty, 2012).

After all, it is certain that the income deficit caused by shrinking export options forced the government to reconsider the domestic political economic system of hydrocarbons in two specific policy areas: the system of subsidies and the involvement of private sector in the energy management. ${ }^{12}$ Obviously, this latter had a negative impact on the economic position of the socalled Iranian Revolutionary Guard, but it pushed the whole industry to a less artificial, commercially and economically more sustainable direction (Yong-Hajihosseini, 2013).

The economic role of the Iranian Revolutionary Guard is based on its privileged political status and as such it takes its share from the ownership and the management of the energy sector. The military intends to monopolize the industry and determines the status of this strategic sector, in order to guarantee the safety of the regime. In this way, the decisions on oil and gas investments, production and utilization rely not only on economic, but political considerations as well (resource nationalism).

The Revolutionary Guard has had its powerful position in the economy since 1989 by means of a subsidiary, the so-called Khatam al-Anbiya ("Seal of the Prophets"), which has approximately 40,000 employees all over the country. The significance of Khatam increased under the presidency of Mahmud Ahmadinejad (2005-2013) who facilitated a nationalistic, state-controlled economy and a hardliner foreign policy (Hassanzadeh, 2014). Due to a state monopoly in the hydrocarbon sector after the withdrawal of international energy companies, Khatam managed to fill the economic void. From this perspective, the sanctions on the energy

\footnotetext{
${ }^{12}$ Since the government was not able to achieve the necessary expansion in electricity generation, transmission and distribution, they started privatization in the electricity sector in 2005. According to estimations, private sector now constitutes only one fifth of the Iranian economy (al-Monitor, 2016b). Private sector involvement is visible in the privatization of generation and distribution sectors of the electricity industry, but the commodity itself belongs to Tavanir (Iran Power Transmission, Generation and Distribution Company) that has a monopoly over the transmission sector (Yousefi et al., 2017). The whole system is supervised by the Ministry of Energy in Iran. For a detailed description of the history and recent developments of the Iranian electricity sector, see Yousefi et al. (2017).
} 
industry were counterproductive, since they indirectly strengthened the position of the state in managing the economy (Unver, 2016). Consequently, it is important to understand the long process of the nuclear talks (concluded by the so-called JCPOA on 14 July 2015) and the following period in which Khatam and the Revolutionary Guard play a special role: this has been a process of economic redistribution within Iran, since the lifting of nuclear sanctions and certain economic restrictions together with the possible inflow of foreign investments might cause degradation in the position of these traditional institutions.

Iran's internal energy management faces serious administrative challenges, because the delimitation of authority among the designated energy policy institutions has become obscure during the sanctions regime. There are different institutions such as Oil Ministry, Energy Ministry and Supreme Energy Council, but the coordination is weak among them and the overlapping fields of responsibility create tensions in many cases (Calder, 2012). The Oil Ministry is a political board, supervising the National Iranian Oil Company (NIOC), one of the largest national oil companies in the world, that manages the oil and natural gas sectors in Iran. Even within NIOC, there is a rivalry among the four main subsidiaries, the National Iranian Gas Company (NIGC), the National Iranian Gas Export Company (NIGEC), the National Iranian Oil Refining \& Distribution Company (NIORDC) and the National Petrochemical Company (NPC). Moreover, NIOC was divided into more than 100 subordinated units since the end of the 90s (Stevens, 2015). The Parliament and the Prime Minister's Office also often politicize the debates on energy issues. This is the case during gas price negotiations with the neighboring countries as well: the political institutions accuse NIOC of the betrayal of the national interest, if it offers lower prices than it is expected by the interested political parties. These internal problems seriously call into question the reputation of Iran as a trustful trade partner and a reliable exporter of hydrocarbon products in the international arena (Jalilvand, 2013). 
Beyond the administrative and management problems of the Iranian oil and gas sectors, the system of state subsidies for fossil energy resources also poses a serious challenge to the creation of an effective, market-based and investor-friendly economic environment for hydrocarbon production. Subsidies for oil products are originated from the Shah's era and survived the regime change in 1979 (after the oil crisis of 1973, it increased from $12 \%$ to $96 \%$ of the commercial price) and extended to natural gas, gasoline and electricity consumption as well. The risk of this policy is that the government has to finance the additional costs caused by negative world market trends creating no price flexibility of these commodities. As a consequence of state commitment to price support, the level of subsidies changed from $11 \%$ of the GDP (gross domestic product) in $1997-1998$, to $17 \%$ in the next year and then to $23 \%$ in 2010 (Calder, 2012; Hassanzadeh, 2014). Altogether, in 2015 the Iranian government paid the largest amount of subsidies of oil, gas and electricity in the world surpassing the degree of subsidies of large consumers such as Saudi Arabia, Russia and Venezuela. (Figure 7)

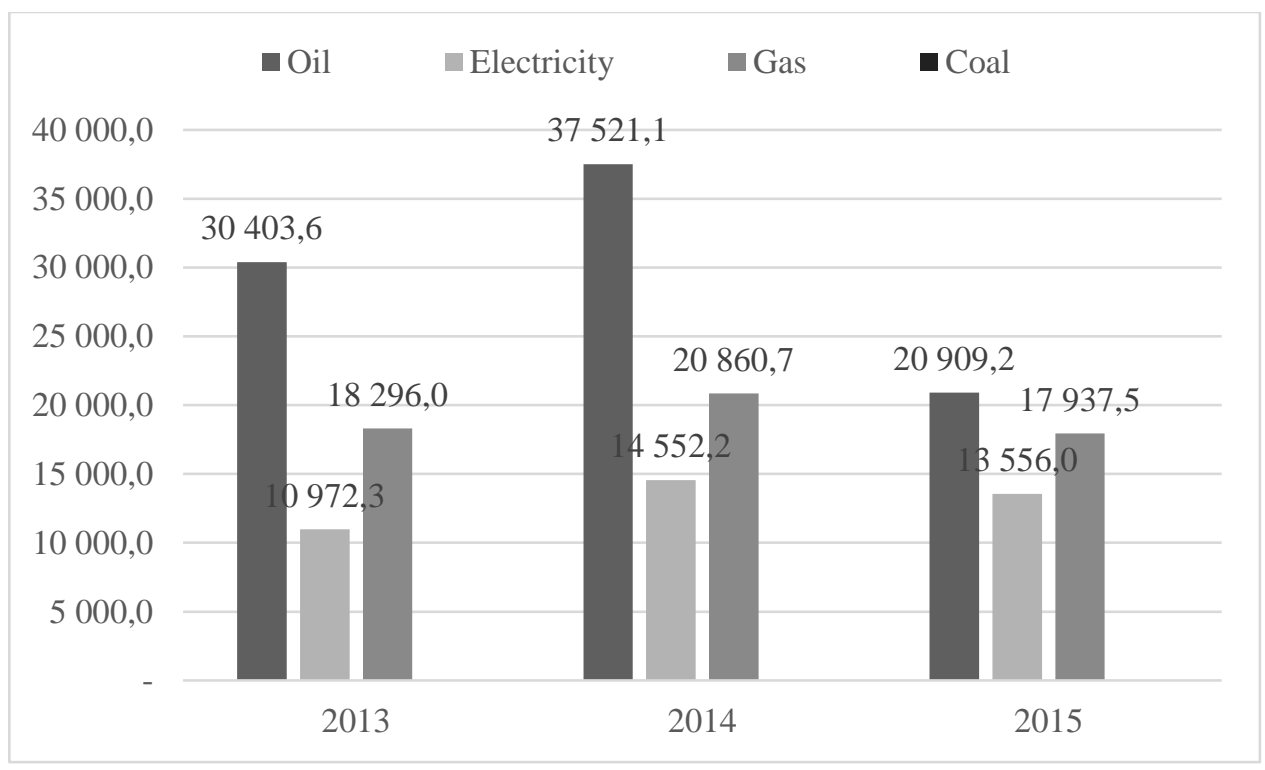

Figure 7. Subsidies in Iran in real 2015 billion USD (IEA 2015)

By the system of subsidies, the government used up the potential investment capacity provided by the upsurge of hydrocarbons for the sake of maintaining a non-productive price 
support system. Paradoxically, this policy helped maintain the profitability of smuggling oil and gasoline to Turkey where the price of gasoline is among the highest in the world (Heuty, 2012). The residential energy consumption growth that went hand in hand with the increasing number of people (due to the population explosion) using more and more motors and cars, worsened the burden of the central budget. (Figure 8) Despite the social policy considerations behind the subsidies and the populist rhetoric of the government, the largest beneficiaries of price supports are the richer urban classes who can afford to use electric devices, air conditioners, cars and motors (Calder, 2012.).

The energy consumption in Iran due to the population growth and the cheap oil and gas has increased eight-fold since 1979, surpassing the growth of GDP two-fold and almost exceeding the increase in gas production. Overconsumption of hydrocarbons grew out of all proportion: energy efficiency (measured through the amount of energy used for producing a certain unit of GDP) in Iran is 6.4 times lower than the OECD average, 3.6 times lower than the world average and even 1.8 lower than the Middle East average (Jalilvand, 2013).

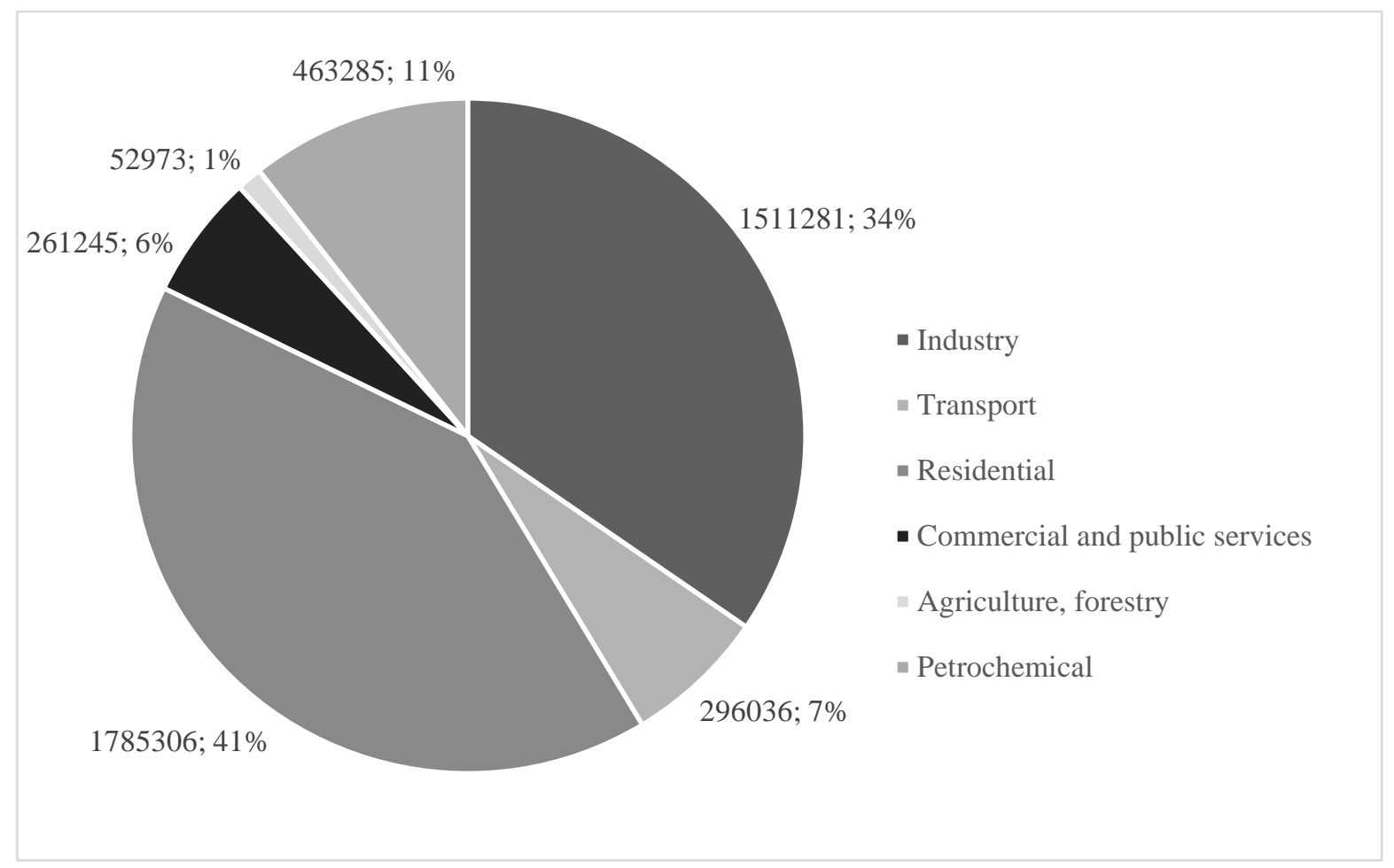




\section{Figure 8. Distribution of domestic gas consumption in Iran on a gross calorific value ba- sis in 2014 (IEA 2015)}

Facing the unsustainability of this budgetary policy, in December 2010 the Iranian government gradually started to adjust the domestic gas price to the gas export price with the aim to reduce the state contribution to $25 \%$ by 2015 (Targeted Energy Subsidies Act). This reform, however, failed in the next year, since $30 \%$ of the consumers could not pay for the gas after having only a lesser price increase, according to a report in April $2011 .{ }^{13}$ As a result, the government halted the program in April 2012 (Hassanzadeh, 2014), disregarding the fact that oil consumption had dropped by $9 \%$, gas $6 \%$, gasoline $26 \%$ and electricity $11 \%$ as a result of the reform (Abbaszadeh, 2013). In 2014, President Rouhani restarted the subsidy reform program; the price of gasoline has begun to approach the market price, thus the level of state subsidy (Vakshouri, 2015) as well as the burden on the central budget decreased (Islamic Republic of Iran, 2015). This positive outcome of reforming price policy strengthened the commitment to further reforms of the subsidies that became evident in the first years of the government led by Hassan Rouhani (2013-). (Figure 9)

\footnotetext{
${ }^{13}$ While the profit of subsidies is disproportionate, policies against subsidies, namely price increase influences every segment of the society due to the general rise of transportation and production fees.
} 


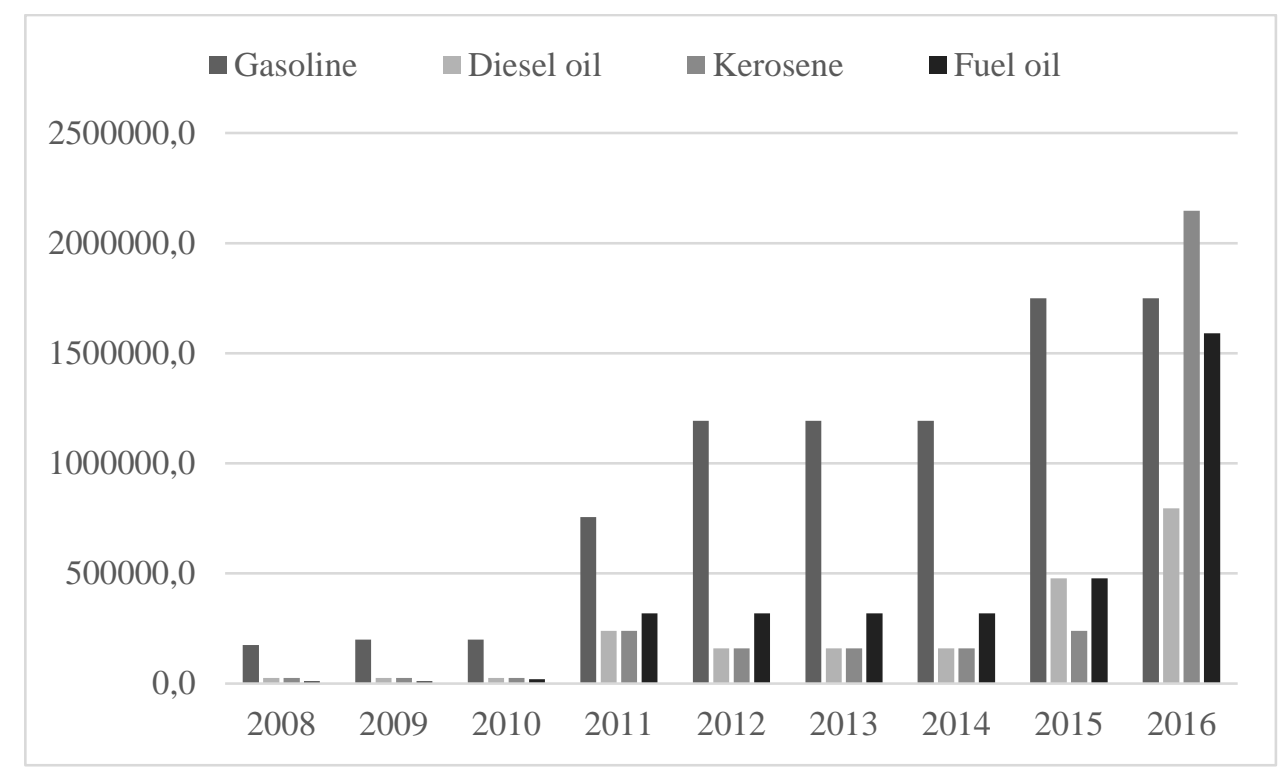

Figure 9. Retail prices of petroleum products in Iran in rial per barrel (OPEC 2013 and OPEC 2017)

\section{After the sanctions: interests and counter interests}

\subsection{An unfinished project}

As the sanctions were lifted after $16^{\text {th }}$ January 2016 , the Iranian oil production has risen to 3.5 million bpd, 0.5 million more than in the beginning of $2016 .{ }^{14}$ This significant growth bears the positive message of high confidence, but the Iranian hydrocarbon sector still has to face a number of difficulties related to the issues partly mentioned above.

Despite considerable improvement, from the perspective of international investors, Iran is still politically, legally and financially a risky country (al-Monitor, 2017c). Long decades of sanctions contributed to the emergence of a non-transparent financial sector. A World Bank record of 2015 ranked Iran $130^{\text {th }}$ out of 189 countries with regard to the easiness of doing business there. (As of 2017, Iran has risen 10 places higher on the same record.) (DoingBusiness, 2017)

\footnotetext{
${ }^{14}$ However, it must be noted that the sudden increase in the Iranian oil output was not the outcome of increase in production. For a long time, Iran had stored unsold oil on ships (40 million barrels in 2015) that has been gradually emptied by Spring 2017 (Reuters, 2017).
} 
Lifting the sanctions is a continuous process with more steps to be taken for the full implementation. For example, the USA has not granted access to the Iranian economy for its investors and for its citizens in general (Jalilvand, 2017). Because of the American policy, many international companies are still cautious about investing in Iran. Although Iran managed to reconnect to the SWIFT (Society for Worldwide Interbank Financial Telecommunication) global banking system, it is still not yet financially integrated into the world economy, since US sanctions blocks the Iranian banks from obtaining dollars from them (Zerohedge, 2017b). As a consequence, European and Asian banks find it difficult to invest in Iran due to a lack of hard and reliable currency in the country (Munro, 2016). This restriction also has a political reason: allegedly, Iran supports terrorist groups such as Hamas and Hezbollah, which Western governments do not want to finance indirectly through the Islamic Republic. ${ }^{15}$ Otherwise, the agreement of 2015 did not stipulate the lift of any further non-nuclear related sanctions (Munro, 2016) and even before the hardliner position of the Trump administration, the Obama administration followed the same decision. This policy partly serves the interests of large international oil companies: British Petroleum, Royal Dutch Shell, South Korean and Indian companies are all indebted to NIOC, valuing up to billions USD. Under financial sanctions, there is no opportunity to pay these debts (Kalehsar, 2015). Besides, some estimate between 100 and 120 billion USD of accounts receivable belonging to the different players of the Iranian economy, that are now frozen; ${ }^{16}$ this amount of money would have played a key role in the development of the Iranian economy (Vakshouri, 2015) even if the country had to repay 50 billion USD national debts (Rzayeva, 2016). Collecting all these assets is a slow process—and several international companies from the hydrocarbon sector and countries with large oil and

\footnotetext{
${ }^{15}$ To strengthen its regional position to the detriment of Western positions, Iran needs to develop its oil and gas sectors to gain extra revenues from export. Paradoxically, to achieve this aim, capital injection of Western powers is necessary.

${ }^{16}$ According to IMF, at the end of 2014-2015 Iranian year, Iranian foreign exchange reserves stood at 127 billion USD (Islamic Republic of Iran, 2015).
} 
gas exporting capacities are uninterested in the swift comeback of a strong Iran to the world market.

As for the American relations, although the new president, Donald Trump is an outright supporter of the sanctions (including the restoration of nuclear sanctions) against Iran, the presidency of Hillary Clinton most probably would not have resulted in significantly better relations with the U.S. ${ }^{17}$ The underlying reason behind the threatening steps made by the Trump administration might be the aim of causing internal difficulties for Iran thus creating an uncertain environment for the European and Asian investors that are in competition with the American oil and gas companies on a global scale (al-Monitor, 2017a). If Iran plays according to the rules, it seems certain that the new American leadership will remain committed to the nuclear agreement and at the same time, will focus on curbing Iran's regional activism and prevent the country from a quick recovery of the strategic economic sectors.

\subsection{Effects of low oil and gas prices}

The fall of oil prices from mid-June 2014 (60\% fall from the peak price) negatively affected the Iranian oil industry. The low prices could not make it possible for the country to benefit from the expansion of oil exports after the nuclear agreement, as much as the profit would have been under earlier conditions. Saudi Arabia, the ideological and geopolitical rival of Iran, exerts a significant influence on the price of oil and the permanent low-price level serves the interest of the Kingdom against Tehran. ${ }^{18}$ Without huge export incomes, it makes the domestic capital accumulation impossible, thus slowing down the recovery of the Iranian hydrocarbon sector (Munro, 2016). Because in the post-sanctions era the Iranian government has not delivered the

\footnotetext{
${ }^{17}$ She argued that since Iran violates the United Nations Security Council resolution on the restriction of ballistic missiles program, the international community has to impose sanctions against the Islamic Republic (Munro, 2016).

${ }^{18}$ Paradoxically, by this price policy, Saudi Arabia indirectly supports the domestic opposition of the Iranian government, an adamant opponent of the Saudi state.
} 
expected high economic results yet (Soufangroup, 2016), the leadership has been facing criticism from the proponents of political and economic isolation of Iran. At the same time, Iran is also not interested in the domestic production cut and growing prices, since that would mean the return of more (mainly shale-based) suppliers and bigger competition in the oil market since higher prices would make their business feasible. For Iran, the production cost for a barrel of oil is around 5-10 USD according to NIOC and maximum 15 USD according to international observers (Lifting sanctions, 2015), therefore it is still valuable if the market gives at least 3540 USD for a barrel, although this amount of money is still below the fiscal break even price of oil in Iran (IMF Middle East and Central Asia, 2017).

The most significant development concerning the international cooperation on oil prices is the agreement made by OPEC in Vienna in 30 November 2016. As the members agreed on cuts from total production of 33.2 million bpd to 32.5-33 million bpd (Mehrnews, 2016), two thirds of reduction were done by Saudi Arabia, Kuwait and the UAE, while the remaining one third was distributed amongst the other seven countries of the organization (with the exception of Libya, Algeria and Iran) (al-Monitor, 2016d). For Iran, the agreement indicated a two-fold advantage: on the one hand, as a consequence of the production cut, the price of oil has increased by $10 \%$, and on the other hand, Iran gained the right to increase its production by 90,000 bpd until its total production reaches the 3.797 million bpd target (al-Monitor, 2016c). Thus the Islamic Republic was able to maintain its growth of 2015 and 2016 in the oil sector.

\subsection{The new type of contract - investment opportunities}

For a long time, the risky legal environment in Iran hindered investments made by IOCs. The so-called buyback contracts first introduced in 1998 have not allowed the non-domestic 
companies to own any assets during the development process of oil or natural gas fields. ${ }^{19}$ This was mutually unfavorable for the Iranians and the IOCs as the buy-back contracts put the international oil companies in a secondary position to the state investor and the short time period of cooperation defined in the contract was not sufficient for the transfer of technology and knowledge for the local contractors. The inefficiency of the buyback contract is further evaluated by Ghandi and Lawell (2017).

The current Iranian leadership, motivated by the post-sanctions expectations, has been trying to create incentives for foreign investors. To achieve this goal, restructuring of the regulatory environment by making it more transparent plays a primary role. As a result of these efforts, the new type of contract, the so-called IPC (Iranian Petroleum Contract) announced first in February 2014, enables the IOCs to explore, develop and exploit new oil and gas fields in cooperation with Iranian companies. This joint venture format makes it possible for the Iranian side to learn the latest and most effective techniques of oil and natural gas production. IPC allows the IOCs the possession of hydrocarbons by transferring Iranian ownership at certain transmission points. This method is in line with the Iranian Constitution, as the foreign company does not acquire ownership right over the assets of the project (al-Monitor, 2016e).

The terms of this new type of contract, aiming to generate new investments in the hydrocarbon sector, were formulated under long internal debates. During the process, not only the interests of Iran and IOCs had to be adjusted, but the contractual conditions provided by other upstream competitors of Iran had to be considered as well ${ }^{20}$ (Stevens, 2015). It was also important to decide on the legal authority in case of a possible dispute between the parties: if Iranian courts are entitled to take measures, it is feared that there might be difficulties for the

\footnotetext{
${ }^{19}$ This requirement was in compliance with the Articles 43 and 45 of the Constitution of the Islamic Republic, which declares that the natural resources of the country belong to the unalienable common goods of the Iranian nation (Jalilvand, 2013).

${ }^{20}$ Long period of negotiation served the idea of building mutual trust between the parties.
} 
international companies to enforce their interests in a legal environment that is unknown and unreliable for foreigners. Beyond certain issues of vested interests, the constant reshuffle of the parties involved made the discussion process even more difficult (Reuters, 2016c). Finally, after two years of negotiation and 150 amendments (Forbes 2016), the IPC in its current form is in accordance with the general terms of the most widely used oil and gas production contracts (alMonitor, 2016e).

Under the framework of IPC, the Iranian government aimed to sign 50 contracts with investors concerning exploration and production (Azernews, 2015). Asian companies that helped maintain the Iranian oil and gas production and development during the years of sanctions (Jalilvand, 2017) were also invited to bid on the upcoming oil and gas investments in Iran. In this sense, there is a geopolitical competition that extends beyond Iran: the competition between East and West, between the newly emerging large consumers of East Asia and the "traditional" IOCs of the developed world.

Within this framework of domestic and international competition, several IOCs from Europe have expressed their interest in the hydrocarbon sector of Iran in the last two years such as French Total, German Wintershall, Norwegian DNO, Dutch Schlumberger, Russian Gazpromneft. However, as long as the conditions of the contracts and the regulatory environment are not fully guaranteed, foreign companies cannot decide on launching the investment process (al-Monitor, 2016f). Although President Rouhani managed to approve 9.1 billion USD foreign investment proposals in every sector of the economy, only 3.1 billion was realized in the Iranian year of 2016-2017 (al-Monitor, 2017d).

Harsh criticisms of the post-sanctions regime and competition in the domestic political arena may cause some uncertainty for investors. However, the decisive electoral success during 19 May 2017 presidential election in Iran, President Rouhani managed to prove the grounds of his reformist policy and maintain the confidence of the Iranian society in the normalization of 
Western relations. Similarly, one year before, during the election of April 2016, "reformist" and "moderate" representatives received a majority in the Parliament sending a positive feedback for the "anti-sanctionist" policy (Munro, 2016). In spite of these developments, "conservative" proponents of the Iranian political system still have the means to influence the direction of reforms, hinder any fundamental changes in the Iranian political structure and maintain their dominance in the economy.

The agreement between Total and NIOC signed on $8^{\text {th }}$ November 2016 is a milestone in the sense that Total is the first Western IOCs to return to the Iranian energy industry after the nuclear agreement of 2015. According to the contract signed on 3 July 2017, Total will receive a 50.1\% stake in the development phase 11 of the South Pars gas field together with the Chinese CNPC $(30 \%)$ and the Iranian Petropars (19.9\%) (al-Monitor, 2016g). This is the first energy investment contract of the post-sanctions era announced as "breaking of the petroleum dam" in the Iranian media. (al-Monitor 2017e) Recently, Shell signed a draft agreement on the study of the second largest Iranian gas field, Kish (NaturalGasWorld, 2016a). The Italian ENI is also interested in the Kish field and have already signed a memorandum of understanding with the Iranian government (Newsbase, 2017). Norwegian firms are ready to help carry out the Caspian offshore drillings (Farsnews, 2017). Similarly, British Petroleum has been looking for a way to take part in investments in Iran without risking its activity in the US (Reuters, 2016d). It is a serious area of concern, since US legislation punishes parallel activities of companies both in Iran and the US. For example, for their doing business with Iranian players under sanctions, European banks suffered 13 billion USD loss by the application of US laws to them (Jalilvand, 2017). In addition to all these important arguments, however, European and Asian companies now have the advantageous position in Iran due to a lack of American competitors. The unambiguous sign of a commitment to the revitalization of energy relations between Iran and 
the EU countries was the first visit of an Iranian oil tanker in Europe after 2012 (in mid-January 2017 in Algeciras, Spain) (al-Monitor, 2017b).

\section{Signs of a prosperous future?}

According to forecasts, in order to produce 4.6 million bpd oil (the target before the OPEC agreement of November 2016), it is necessary for the Iranian oil sector to attract 135 billion USD investment in the next five years. From this amount of money, the Iranian government plans to acquire 30 billion from international contributors (Munro, 2016). Nevertheless, between 2005 and 2010, Iran was able to invest only 10 billion USD for oil exploration and production, therefore the target number defined above seems exaggerated (Kalehsar, 2015).

The government envisaged large scale investments in the natural gas sector as well: through the allocation of 34 billion USD, Iran plans to increase the number of gas compressors from 76 to 105 by 2020 and enlarge the existing gas network to $40,000 \mathrm{~km}$ by $5,000 \mathrm{~km}$ additional pipeline. Iran intends to extend the gas storage capacity from $3 \mathrm{bcm}$ to $11.5 \mathrm{bcm}$ by building eight reservoirs by 2018. Five of them are planned to be constructed in the north and northeastern parts of the country that suffer the most from the consequences of seasonal gas shortages (NaturalGasWorld, 2017b). The basic aim of oil and gas management in Iran is to replace the less efficient domestic oil consumption with more efficient natural gas for the power generation leaving more oil for export to the international market (Hassanzadeh, 2014). The implementation of this policy together with the population and consumption growth contribute to the estimated $10 \%$ growth in the demand for natural gas in the residential sector by 2020 (Rzayeva, 2016).

There are considerable opportunities in the market of petrochemicals where the processing of oil and natural gas creates value added products. In this sector, the sanctions generated capacity building with the aim of fulfilling the domestic needs (Wang, 2017). The current daily 
oil refinery capacity of the country is about 1.7 million barrels, although only the $70 \%$ is utilized as such due to the large amount of residential consumption (Rzayeva, 2016). The largest refineries are the Arak (Middle Iran), Lavan, and Bandar Abbas (both in the south) (Vakshouri, 2015). All nine oil refinery units are operated by the NIOC subsidiary, the National Iranian Oil Refining and Distribution Company (NIORDC) (Wang, 2017).

In 2014 Iran produced 40 million tons of petrochemical products (for which $13 \mathrm{bcm}$ natural gas was used) making the Islamic Republic the biggest petrochemical producer in the MENA (Middle East and North Africa) region. ${ }^{21}$ Since domestic consumption is considerably significant in this regard as well, there are projections about additional export capacity-building in the future (Rzayeva, 2016). As a result of the latest developments, in cooperation with Chinese, South Korean and Japanese capital investment, Iran started to build 12 oil and gas condensate refinery complexes to the value of 8.6 billion USD (Oilpro, 2016a). The Persian Gulf Star refinery is expected to be online with its 360,000 bpd capacity in 2018 , while three other complexes, the Siraf (400,000 bpd), the Bahman Geno (300,000 bpd) and the Anahita (150,000 bpd) will have started operations by 2021 (Trend, 2016). These refineries will serve the purpose of producing gasoline, kerosene, petrol, LPG (autogas) and other refined oil and gas products. In this field, the Iranians have a comparative advantage over other Middle Eastern producers (mainly the Gulf States) due to the more abundant supply of raw materials (IHS Markit, 2017). The East Asian companies have been taking the most advantage of these potential: in accordance with an agreement signed between Iran and Indonesia in August 2016, Iran promised to transport 600,000 tons of LPG to the Southeast Asian country (Oilpro, 2016b).

\footnotetext{
${ }^{21}$ The large expansion of the Iranian petrochemical industry can be accredited to the former period in office (19972005) of the current oil minister, Bijan Zangeneh (Vakshouri, 2015).
} 
Altogether non-oil exports in the Iranian year of 2016 (ended on 20 March 2017) have increased more than 30 percent $^{22}$ (Zawya, 2017).

For the successful export of Iranian gas, at least three factors are necessary: (1) intensification of production (that surpasses the ever-growing domestic consumption), (2) modernization of infrastructure in Iran and in the neighborhood, (3) development of LNG technology in the southern ports of Iran to connect to world natural gas markets. For these purposes, the Iranian hydrocarbon sector needs technological and financial assistance from international oil companies to provide the latest innovations and assets for both upstream and downstream developments in the country. It seems that the government is committed to defining its policy targets along these principles. (Table 4.)

\begin{tabular}{|c|c|c|}
\hline 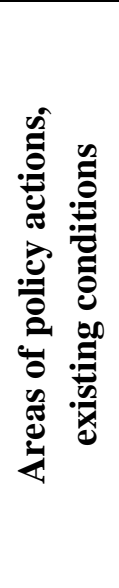 & $\begin{array}{l}\text { Strength (+) } \\
\text { - } \quad \text { Huge hydrocarbon reserves (i1) } \\
\text { - } \quad \begin{array}{l}\text { Better chance of success in explorations } \\
\text { (compared to other countries) (i1) }\end{array} \\
\text { - } \quad \begin{array}{l}\text { No American competition for the IOCs } \\
\text { (compared to other countries) (i2) (i3) }\end{array} \\
\text { - } \quad \text { Comparative advantage in the Iranian pet- } \\
\text { - } \quad \text { Gochemical sector (i1) (i2) } \\
\text { - } \quad \text { IPC contract defined (i2) }\end{array}$ & 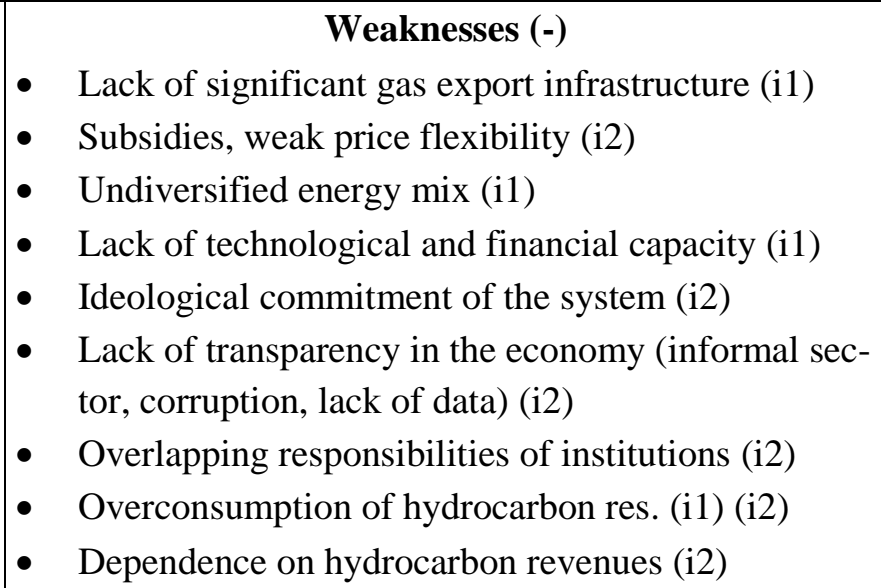 \\
\hline 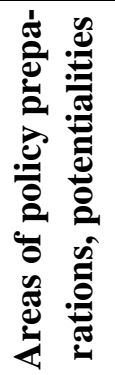 & \begin{tabular}{ll}
\multicolumn{1}{c}{ Opportunities (+) } \\
- & Growing hydrocarbon market (i1) \\
- & Natural gas export to East Asia (i1) (i3) \\
- & Governmental commitment to investments \\
- & in the hydrocarbon sector (i1) (i2) \\
- & Peaceful area in the Middle East (i3) \\
\end{tabular} & \begin{tabular}{ll} 
- & \multicolumn{1}{c}{ Threats (-) } \\
- & Low oil price (i3) \\
- & World market oversupply (new producers) (i3) \\
- & US threats with denouncing the JCPOA (i3) \\
- & Intensification of conflicts in the MENA (i3) \\
- & Growing domestic gas consumption (i1) (i2)
\end{tabular} \\
\hline
\end{tabular}

Table 3. SWOT analysis of the Iranian hydrocarbon sector infrastructural background (i1); institutional basis (i2); international impacts (i3)

\footnotetext{
${ }^{22}$ For a more detailed discussion of investment opportunities in the Iranian petrochemical industry see Iran's Petrochemical Industry Report (2014) and Vakhshouri (2017).
} 
Beyond the opportunities, challenges and uncertainties mentioned above, the most significant growth potential in the short run lies in the natural gas sector. According to certain estimations, Iran will be able to export $24.6 \mathrm{bcm}$ natural gas within five years (Tanchum, 2015 and Rzayeva, 2016). The Iranian plan to reconnect its hydrocarbon industry to the global energy market will undoubtedly have a massive effect on the existing regional and global "energeopolitical" dynamics. This can be considered as a potential field for future studies and the author intends to analyze the geopolitical environment of Iranian oil and gas industries in an additional article in the future.

\section{Policy recommendations and conclusion}

To counter the existing weaknesses and potential threats of the Iranian hydrocarbon sector, the Iranian leadership needs to implement changes in the infrastructural background and the institutional basis of oil and gas industries and address the international impacts on these strategic sectors. As a general rule, Iran needs to utilize the existing strengths and potential opportunities to fully address the domestic and international challenges of the oil and gas industries.

Infrastructural background (i1)

- Transferring money to other, non-hydrocarbon sectors (diversification of the economy)

- Putting more emphasis on the renewable power sources (diversification of the energy mix)

- Strengthening the low flexibility of energy systems by building more transmission lines and brokering swap deals with neighbors

Institutional basis (i2)

- Establishing a competitive environment for both the public and the private sectors

- Creating clear institutional responsibilities without overlapping duties

- Strengthening the authority of the existing institutional background, decreasing the role of informal political and economic networks 
- Developing a new business culture based on efficiency, accountability, and performance

- Decentralization of the economic structure

- Audits of sectorial players and regular reports on their activities

- Creating a predictable environment, therefore minimizing the risks created by political arbitrariness

International impacts (i3)

- Balancing the differences between the consumer and the market price of energy

- Finding a delicate balance between international companies and local production units

- Fostering greater interaction between Iran and the international capital, workforce and technology (integration into the world economy)

Iran seems to be in transition to a more effective energy structure. In the last years, there is a clear shift from the ideological considerations to a more pragmatic approach in the management of the Iranian economy and the strategic resources. Under these circumstances, building trust is essential, but it is a longer process by its nature. This enduring shift in Iran might be a good showcase of how a closed economy rich in hydrocarbon resources can alter its ideological and political structure step by step from within. In this process of transformation, beyond the internal initiatives, external factors also play a significant role as it has been shown, and in this sense, the responsibility of the international community to meet the reformist agenda of Iran is crucial. All things considered, it is worth keeping only the lower expectations concerning the upcoming production boom of the Iranian hydrocarbon industry: due to external market tendencies (low oil price, oversupply in the market) and the internal redistribution of economic assets among the interested parties, the most probable scenario proposes a slow and continuous transformation in the oil and gas sectors of the Islamic Republic. In practice, it means that both the extension of export capacity and the involvement of international companies will take place in 
a gradual, regulated way, in which all the interests of major Iranian political and economic stakeholders will be considered.

\section{Acknowledgements}

The author expresses his gratitude to his mentor, Prof. Erzsébet N. Rózsa (National University of Public Service, Hungary) for her dedicated help in shaping and revising this article. Special thanks belong to Dr. Péter Marton (Corvinus University of Budapest) for his invaluable comments and Saad Bashir (Georgetown University, Washington) for the language correction. The author is grateful for the organizers, participants, lecturers and professors of the $11^{\text {th }}$ Baku Summer Energy School for providing an inspirational environment during the last phase of writing.

This work was financially supported by the Doctoral Research Excellence Award of the Hungarian National Bank. Some of the literature used in this study was provided by the financial support of the Hungarian National Talent Program.

\section{References}

Abbaszadeh et al., 2013: Iran's oil development scenarios by 2025. Energy Policy 56, $612-$ 622.

Ansari, A.M., 2010. Crisis of Authority: Iran's 2009 Presidential Election, Chatham House.

Azadi, A. K., Yarmohammad, M. H., 2011. Analysis of Iran's crude oil export future capacity. Energy Policy 39, 3316-3326.

Bahgat, G., 2015. Geopolitics of Energy: Iran, Turkey, and Europe. Mediterranean Quarterly. 26:3, pp. 49-66. 
Bárdossy Gy., 2007. Irán geológiája és geográfiája [The geology and geography of Iran], in: Jeremiás Éva M., (Ed.), Iráni föld - perzsa kultúra [Iranian land - Persian culture]. Avicenna Közel-Kelet Kutatások Intézete, Piliscsaba, pp. 433-448.

BP 2017. BP Statistical Review of World Energy, June 2017.

Calder, K.E., 2012. The New Continentalism. Energy and Twenty-First-Century Eurasian Geopolitics, Yale University Press.

CCEE, 2014. Options for Delivering Iranian Gas to Europe via Turkey. CCEE Policy Brief. No. 5., May 2004.

David, S.R. 1991. Explaining third world alignment. World Politics, Vol. 43. No. 2 (Jan 1991).

Esen, V., Oral, B., 2016. Natural gas reserve/production ratio in Russia, Iran, Qatar and Turkmenistan: A political and economic perspective. Energy Policy 93 (2016), pp. 101-109.

Eshraghi, H., Ahadi, M.S., 2016. An initiative towards an energy and environment scheme for Iran: Introducing RAISE (Richest Alternatives for Implementation to Supply Energy) model. Energy Policy 89, pp. 36-51.

Ghandi, A. and Lawell, C.-Y. C.L., 2017. On the rate of return and risk factors to international oil companies in Iran's buy-back service contracts. Energy Policy 103, 16-29.

GSN, 2016. Amid shifting global gas supply, Gulf states emerge as their own best market. Gulf States News. Volume 40., Issue 1019, 14 July 2016.

Hassanzadeh, E., 2014. Iran's natural gas industry in the post-revolutionary period. Optimism, scepticism, and potential. The Oxford Institute for Energy Studies.

Heuty, A. 2012. A Ticking Bomb? Iran's Oil and Gas Management. Revenue Watch Institute Briefing, February 2012.

IMF Middle East and Central Asia. Regional Outlook Reflecting Global Developments. April 2017. 
Iran 2017 Budget: Oil \& taxes buttress revenues. Arabia Monitor, January 2017.

Iran's Petrochemical Industry Report. Annual Report, NPC, 2014.

Islamic Republic of Iran. IMF Country Report No. 15/349, December 2015.

Jafari, H.H., Baratimalayeri, A., 2008. The crisis of gasoline consumption in the Iran's transportation sector. Energy Policy 36, 2536-2543.

Jalilvand, D.R., 2013. Iran's gas exports: can past failure become future success? The Oxford Institute for Energy Studies.

Jalilvand, D.R., 2017. Iranian Energy: a comeback with hurdles. The Oxford Institute for Energy Studies.

Kalehsar, O.S., 2015. Iran Energy Sector Post Sanctions, in: Çomak, Prof. Dr. H. et al. (eds.), Enerji Diplomasisi [Energy diplomacy]. Beta Basım, İstanbul, pp. 411-440.

Kiani, B. and Pourfakhraei, M.A. 2010. A system dynamic model for production and consumption policy in Iran oil and gas sector. Energy Policy 38 (2010), pp. 7764-7774.

Lektzian, D. J. et al., 2007. Sanctions, Signals, and Militarized Conflict. American Journal of Political Science, Vol. 51. No. 2 (Apr 2007), pp. 415-431.

Lifting Sanctions on Iran. Implications for the Global Oil Market. CCEE Policy Brief, No.21., December 2015.

Magri, P., Perteghella, A. (eds.), 2015. Iran After the Deal: The Road Ahead. ISPI.

Mojtahed, A., 2012. The Illusion of Unlimited Supply: Iran and Energy Subsidies. in: Shaffer, B. et al. (eds.), Beyond the Resource Curse. University of Pennsylvania Press, pp. 110 136.

Moshiri, S., 2015. The effects of the energy prices reform on households consumption in Iran. Energy Policy 79 (2015). pp. 177-188.

Munro, D., 2016. Past Imperfect, Future Tense: Iran's Oil Industry Post-Sanctions. The Arab Gulf States Institute in Washington. 
Oil sanctions on Iran: Cracking under pressure? A special report from the Economist Intelligence Unit, 2012.

OPEC 2009. OPEC Annual Statistical Bulletin 2009.

OPEC 2010-2011. OPEC Annual Statistical Bulletin 2010-2011.

OPEC 2012. OPEC Annual Statistical Bulletin 2012.

OPEC 2013. OPEC Annual Statistical Bulletin 2013.

OPEC 2017. OPEC Annual Statistical Bulletin 2017.

Parsi, T., 2013. A Single Roll of the Dice. Obama's Diplomacy with Iran. Yale University Press.

Posch W. (ed.), 2006. Iranian Challenges, Chaillot Paper, No. 89, May 2006.

Rzayeva, G., 2016. Post-Sanction Iranian Natural Gas Production and Export Potential: Challenges and Opportunities. CEDIGAZ Insights, No. 19.

Smith, B., 2007. Hard Times in the Lands of Plenty. Oil Politics in Iran and Indonesia. Cornell University Press.

Social Change in Post-Khomeini Iran. Working Group Summary Report, No. 10. Center for International and Regional Studies, Georgetown University School of Foreign Service in Qatar, 2013.

Sovacool, B. K., 2014. What are we doing here? Analyzing fifteen years of energy scholarship and proposing a social science research agenda. Energy Research \& and Social Science 1 (2014) pp. 1-29.

Stevens, P., 2015. Prospects for Iran's Oil and Gas Sector. Chatham House Research Paper.

Tabatabaei et al., 2017. Economic, welfare and environmental impact of feed-in tariff policy: A case study in Iran. Energy Policy 102, pp. 164-169.

Talaei, A. et al., 2014. Climate friendly technology transfer in the energy sector: A case study of Iran. Energy Policy 64, pp. 349-363. 
Tanchum, M., 2015. A Post-Sanctions Iran and the Eurasian Energy Architecture. Challenges and Opportunities for the Euro-Atlantic Community. Atlantic Council.

Unver, H.A., 2016. Turkish-Iranian Energy Cooperation and Conflict: The Regional Politics. Middle East Policy. Vol. XXIII, No. 2.

Vakhshouri, S., 2015. Iran's Energy Policy after the Nuclear Deal. Atlantic Council.

Vakhshouri, S., 2017. Post-Vienna: Prospects for Iran's oil production and exports. Atlantic Council Issue Brief, January 2017.

Wang, H.K.H., 2017. Energy Markets in Emerging Economies. Strategies for growth. Routledge.

Yong, W., Hajihosseini, A., 2013. Understanding Iran Under Sanctions: Oil and National Budget. The Oxford Institute for Energy Studies.

Yousefi et al., 2017. Electricity industry restructuring in Iran. Energy Policy 108, pp. 212 226.

\section{Web references}

al-Monitor, 2016a. Why renewable energy is booming in Iran. http://www.al-monitor.com/pulse/originals/2016/10/iran-renewable-energy-bushehr-wind-solar-developmentplan.html\#ixzz4RiZzfBo1 accessed 25.07.17.

al-Monitor, 2016b. Why Iran's private sector hasn't benefited from privatization.

http://www.al-monitor.com/pulse/originals/2016/11/iran-privatization-private-sector-impact-pension-funds.html\#ixzz4ZywQtGQ0 accessed 25.07.17.

al-Monitor, 2016c. Iranian media praises OPEC deal as victory over Saudi Arabia. http://www.al-monitor.com/pulse/originals/2016/12/iran-media-reaction-opec-output-dealvictory-saudi-arabia.html\#ixzz4Zz4MrJPq accessed 25.07.17. 
al-Monitor, 2016d. Why OPEC deal is double-edged sword for Iran. http://www.al-monitor.com/pulse/originals/2016/12/iran-opec-deal-reaction-saudi-quota-benefits.html\#ixzz4Zz4kEyv8 accessed 25.07.17.

al-Monitor, 2016e. Will Iran attract international oil firms in post-sanctions era? http://www.al-monitor.com/pulse/originals/2016/11/iran-petroleum-contract-ipc-totalcnpc-azadegan.html\#ixzz4Zz5pNL7b accessed 25.07.17.

al-Monitor, 2016f. What's fueling opposition to Iran's new oil contracts? http://www.al-monitor.com/pulse/originals/2016/05/iran-petroleum-contract-framework-delayed.html\#ixzz4Zz768ZpT accessed 25.07.17.

al-Monitor, 2016g. Will Total deal pave way for other oil majors' return to Iran? http://www.al-monitor.com/pulse/originals/2016/11/total-cnpc-iran-south-pars-return-international-oil-majors.html\#ixzz4Zz7QMheI accessed 25.07.17.

al-Monitor, 2017a. How Trump is already shifting domestic politics in Iran? http://www.almonitor.com/pulse/originals/2017/02/iran-reactions-trump-rhetoric-domestic-politics-impact.html\#ixzz4Zz5Lww00 accessed 25.07.17.

al-Monitor, 2017b. Resumption of Iranian oil shipping off to slow start. http://www.al-monitor.com/pulse/originals/2017/02/iran-oil-tanker-shipping-nitc-sanctions-nuclear-dealspain.html\#ixzz4Zz8eK4lt accessed 25.07.17.

al-Monitor, 2017c. Can Iran avoid looming banking crisis? http://www.al-monitor.com/pulse/originals/2017/03/iran-looming-banking-crisis-qe-program-cbiseif.html\#ixzz4nTZDX7hP accessed 25.07.17.

al-Monitor, 2017d. Europe must adopt long-term vision for trade with Iran. http://www.almonitor.com/pulse/originals/2017/07/iran-europe-trade-post-sanctions-era-conditionstrade-invest.html\#ixzz4nPNEzYig accessed 25.07.17. 
al-Monitor, 2017e. Iran signs first energy contract since nuclear deal. http://www.al-monitor.com/pulse/originals/2017/07/iran-total-france-south-pars-gas-deal-criticism.html accessed 25.07.17.

Azernews, 2015. Details of 21 Iranian gas fields, offered to foreigners. http://www.azernews.az/region/90492.html accessed 25.07.17.

DoingBusiness, 2017. Economy Rankings. http://www.doingbusiness.org/rankings accessed 25.07.17.

Farsnews, 2017. Official: Norwegian Firms to Help Iran in Caspian Sea Offshore Drilling, Exploration projects. http://en.farsnews.com/newstext.aspx?nn=13960220000483 accessed 25.07.17.

Forbes, 2016. As Iran Reopens To The International Oil Business, Risks Abound For Foreign Companies. https://www.forbes.com/sites/michaellynch/2016/09/02/iran-reopens-to-theinternational-oil-business/\#227ff90e5afd accessed 25.07.17.

Gazprom, 2014. Gazprom increasing its stake in ArmRosgazprom to 100 per cent. http://www.gazprom.com/press/news/2014/january/article182633/ accessed 25.07.17.

IEA 2014. IEA Report, 2014. https://www.iea.org/statistics/statisticssearch/report/?coun$\underline{\text { try}=I R A N \& p r o d u c t}=$ naturalgas $\&$ year $=2014$

IEA 2015. IEA fossil-fuel subsidies database, https://www.iea.org/media/statistics/Subsidies20132015.xlsx

IHS Markit, 2017. Sanctions Relief Strengthens Outlook for Iranian Petrochemical Producer NPC Iran, as Capacity, Exports Expected to Rise, IHS Markit Says. http://news.ihsmarkit.com/press-release/sanctions-relief-strengthens-outlook-iranian-petrochemical-producer-npc-iran-capacity- accessed 25.07.17.

IMF, 2015. Islamic Republic of Iran. IMF Country Report No. 15/349. http://www.imf.org/external/pubs/ft/scr/2015/cr15349.pdf accessed 25.07.17. 
Investiran, 2017. Oil \& Gas Overview. http://www.investiniran.ir/en/sectors/oilandgas accessed 25.07.17.

Mehrnews, 2016. OPEC to limit oil production, Iran exempt from cut plan. http://en.mehrnews.com/news/121685/OPEC-to-limit-oil-production-Iran-exempt-fromcut-plan accessed 25.07.17.

NaturalGasWorld, 2016a. Shell to study Iranian giant. http://www.naturalgasworld.com/shellto-study-iranian-giant-34802 accessed 25.07.17.

NaturalGasWorld, 2017a. Iran adds 1 trillion $\mathrm{m}^{3}$ to gas reserves. http://www.naturalgasworld.com/iran-adds-1tr-m3-to-gas-reserves-35782 accessed 25.07.17.

NaturalGasWorld, 2017b. Iran acts to offset import cut. http://www.naturalgasworld.com/iran-acts-to-offset-import-cut-35383 accessed 25.07.17.

Newsbase, 2017. After Rouhani Re-Election, Eni And Total Move Ahead In Iran. https://newsbase.com/topstories/after-rouhani-re-election-eni-and-total-move-ahead-iran accessed 25.07.17.

Oilpro, 2016a. Iran expands refinery plans. http://oilpro.com/announcement/4521/iran-expands-refinery-plans accessed 25.07.17.

Oilpro, 2016b. Iran signs deal for Pertamina to develop Ab-Teimour and Mansouri fields. http://oilpro.com/announcement/3886/iran-signs-deal-pertamina-to-develop-ab-teimourand-mansouri-fiel accessed 25.07.17.

Oilpro, 2017. Iran seeks quick start-up while Trump fears remain. http://oilpro.com/post/30551/iran-seeks-quick-start-up-while-trump-fears-remain accessed 25.07.17.

OurWorld, 2014. The Emerging Iranian-Turkish Energy Partnership: Strategic Implications. https://ourworld.unu.edu/en/the-emerging-iranian-turkish-energy-partnership-strategic-implications accessed 25.07.17. 
Reuters, 2016a. Airbus plan heralds Iran boom after sanctions lifted. http://www.reuters.com/article/us-iran-nuclear-economy-idUSKCNOUV0GB accessed 25.07.17.

Reuters, 2016b. Iran oil exports hit pre-sanctions high on run-up in condensate shipments. http://www.reuters.com/article/us-iran-oil-idUSKCN124001 accessed 25.07.17.

Reuters, 2016c. As Iran oil tenders near, investors still in the dark on terms. http://www.reuters.com/article/us-iran-oil-contracts-idUSKCN12K1M1 accessed 25.07.17.

Reuters, 2016d. Exclusive: BP ring-fences CEO Dudley from Iran decision-making. http://www.reuters.com/article/us-bp-iran-idUSKBN13G1PU accessed 25.07.17.

Reuters, 2017. Iran struggles to expand oil exports as sea storage cleared. http://www.reuters.com/article/us-iran-oil-storage-idUSKBN1780H6 accessed 25.07.17.

Shana, 2014. NITC, the 2nd Largest Oil Tanker Fleet in the World. http://www.shana.ir/en/newsagency/212139/NITC-the-2nd-Largest-Oil-Tanker-Fleet-inthe-World accessed 25.07.17.

Trend, 2016. Iran cementing its position in petroleum products market. http://en.trend.az/iran/business/2668210.html accessed 25.07.17.

WEO 2015. World Energy Outlook, 2015. http://www.worldenergyoutlook.org/resources/energysubsidies/

Zawya, 2017. Iran boasts of economic break from oil. https://www.zawya.com/mena/en/story/Iran_boasts_of_economic_break_from_oilZAWYA20170418032256/ accessed 25.07.17.

Zerohedge, 2017a. 64 Years Later, CIA Finally Releases Details Of Iranian Coup. http://www.zerohedge.com/news/2017-06-21/64-years-later-cia-finally-releases-detailsiranian-coup accessed 25.07.17. 
Zerohedge, 2017b. Russia And Iran Sign Oil-For-Goods Barter Deal; Escape Petrodollar. http://www.zerohedge.com/news/2017-05-28/russia-and-iran-sign-oil-goods-barter-dealescape-petrodollar accessed 25.07.17.

\section{Appendix}

$\mathrm{bcm}$ - billion cubic meters

bpd - barrel per day

CNPC - Chinese National Petroleum Company

EU - European Union

GDP - gross domestic product

JCPOA - Joint Comprehensive Plan of Action (nuclear agreement)

LNG - liquified natural gas

LPG - autogas

MENA - Middle East and North Africa

NIOC - National Iranian Oil Company

OPEC - Oil and Petroleum Exporting Countries

SWIFT - Society for Worldwide Interbank Financial Telecommunication

USD - United States dollar 